\title{
Additional Phase II Testing at 41BX323 in Brackenridge Park, San Antonio, Bexar County, Texas
}

Antonia L. Figueroa

Center for Archeological Research, University of Texas at San Antonio

Jon J. Dowling

Follow this and additional works at: https://scholarworks.sfasu.edu/ita

Part of the American Material Culture Commons, Archaeological Anthropology Commons, Environmental Studies Commons, Other American Studies Commons, Other Arts and Humanities Commons, Other History of Art, Architecture, and Archaeology Commons, and the United States History Commons

Tell us how this article helped you.

This Article is brought to you for free and open access by the Center for Regional Heritage Research at SFA ScholarWorks. It has been accepted for inclusion in Index of Texas Archaeology: Open Access Gray Literature from the Lone Star State by an authorized editor of SFA ScholarWorks. For more information, please contact cdsscholarworks@sfasu.edu. 
Additional Phase II Testing at 41BX323 in Brackenridge Park, San Antonio, Bexar County, Texas

\section{Creative Commons License}

\section{(c) (1) (8)}

This work is licensed under a Creative Commons Attribution-NonCommercial 4.0 International License 


\section{Additional Phase II Testing at 41 BX323 in Brackenridge Park, San Antonio, Bexar County, Texas}

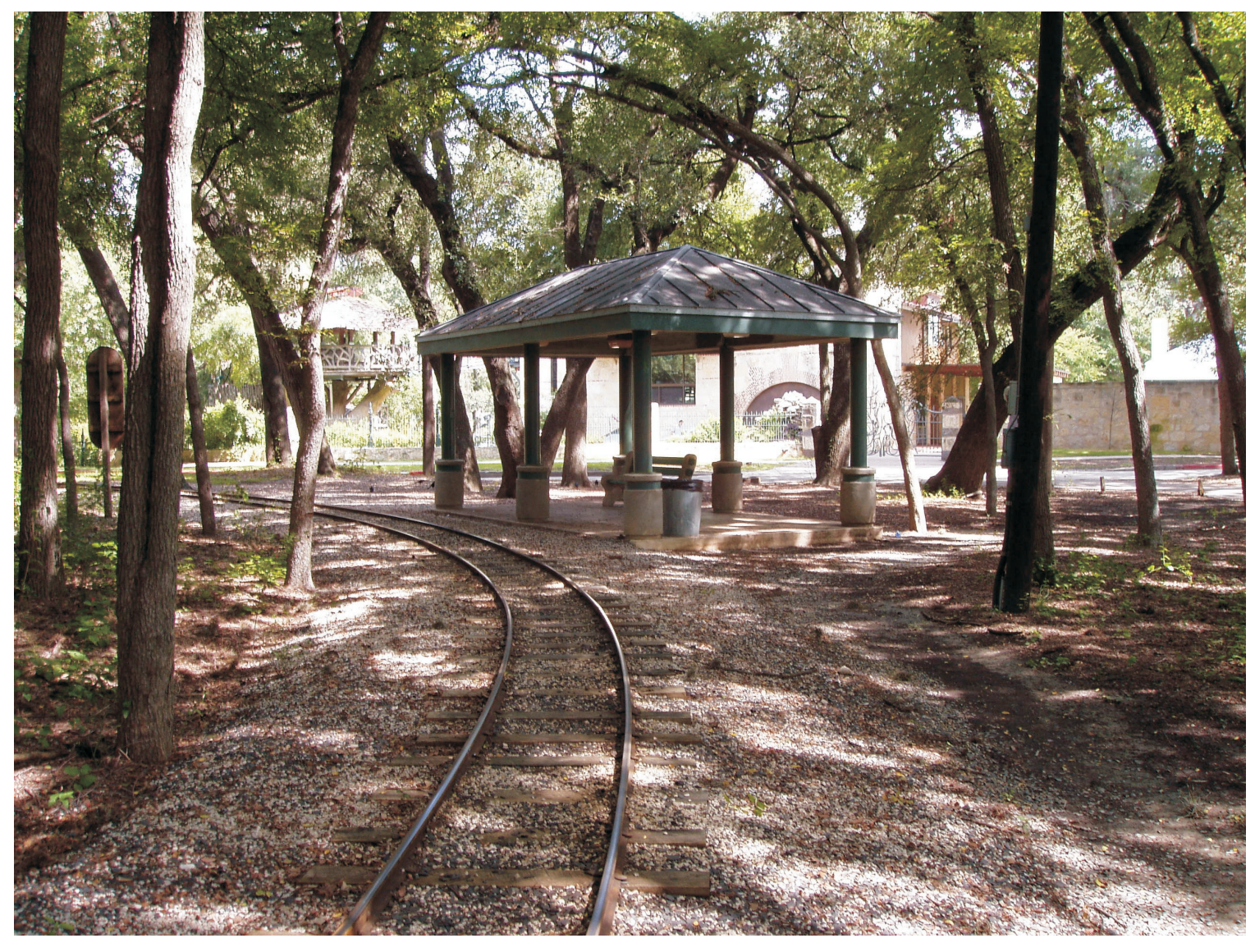

by

Antonia L. Figueroa and Jon J. Dowling

Prepared for:

Lake/Flato Architects

311 Third Street

San Antonio, Texas 78250

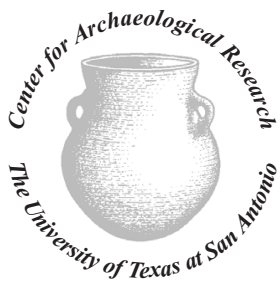

(C)2007
Prepared by:

Center for Archaeological Research The University of Texas at San Antonio Archaeological Report, No. 377 


\section{Additional Phase II Testing at $41 \mathrm{BX} 323$ in Brackenridge Park, San Antonio, Bexar County, Texas}

by

Antonia L. Figueroa and Jon J. Dowling

Texas Antiquities Committee Permit No. 4647

Principal Investigator

Steve A. Tomka

Prepared for:

Lake/Flato Architects

311 Third Street

San Antonio, Texas 78250
Prepared by:

Center for Archaeological Research

The University of Texas at San Antonio Archaeological Report, No. 377 
A list of publications offered by the Center for Archaeological Research is available. Call (210) 458-4378; write to the Center for Archaeological Research, The University of Texas at San Antonio, One UTSA Circle, San Antonio, Texas 78249-1644; e-mail to car@utsa.edu; or visit CAR's web site at http://car.utsa.edu. 


\begin{abstract}
:
The Center for Archaeological Research at The University of Texas at San Antonio (CAR-UTSA) conducted eligibility testing on the southeast portion of 41BX323, Bexar County, Texas from September 6 to September 14, 2007. CAR was contracted by Lake/Flato Architects to conduct eligibility testing on a previously uninvestigated portion of site 41BX323. Lake/Flato Architects have been contracted by the City of San Antonio Parks and Recreation Department for the construction of a proposed parking garage facility. The proposed improvements will be impacting the southeastern portions of State Archaeological Landmark (SAL) site 41BX323. The primary goal of the excavations was to determine if the proposed impacts would adversely affect deposits that contribute to the site's SAL eligibility. A second goal was to better define the southern boundary of the site. Testing by CAR concluded that the site boundaries need to be extended further south than previously recorded. CAR concludes that the cultural material recovered during excavations likely represents a Late Prehistoric to Archaic occupation of the site. CAR identified no significant data, within the tested portion of the site that would contribute to the understanding of prehistoric Texas. No intact features were identified although small pieces of fire-cracked rock was quite common on site. Following the review of the draft final report, the THC reviewer, Mark Denton, requested that the City Parks and Recreation Department coordinate with the THC regarding the movement of the maintenance facility found within the boundaries of the project area. In addition, the THC requested that Lake/Flato Architecs coordinate with the THC regarding the relocation of the mini-rail road from within the footprint of the planned parking facility. Since the new location will fall within the limits of site 41BX323, it is paramount that no subsurface disturbances occur during the reinstallation of the tracts. All materials recovered during the investigations and all project related documents are curated at the Center for Archaeological Research. CAR recommends that the tested portion of the site does not contribute to the site's SAL eligibility.
\end{abstract}




\section{Table of Contents:}

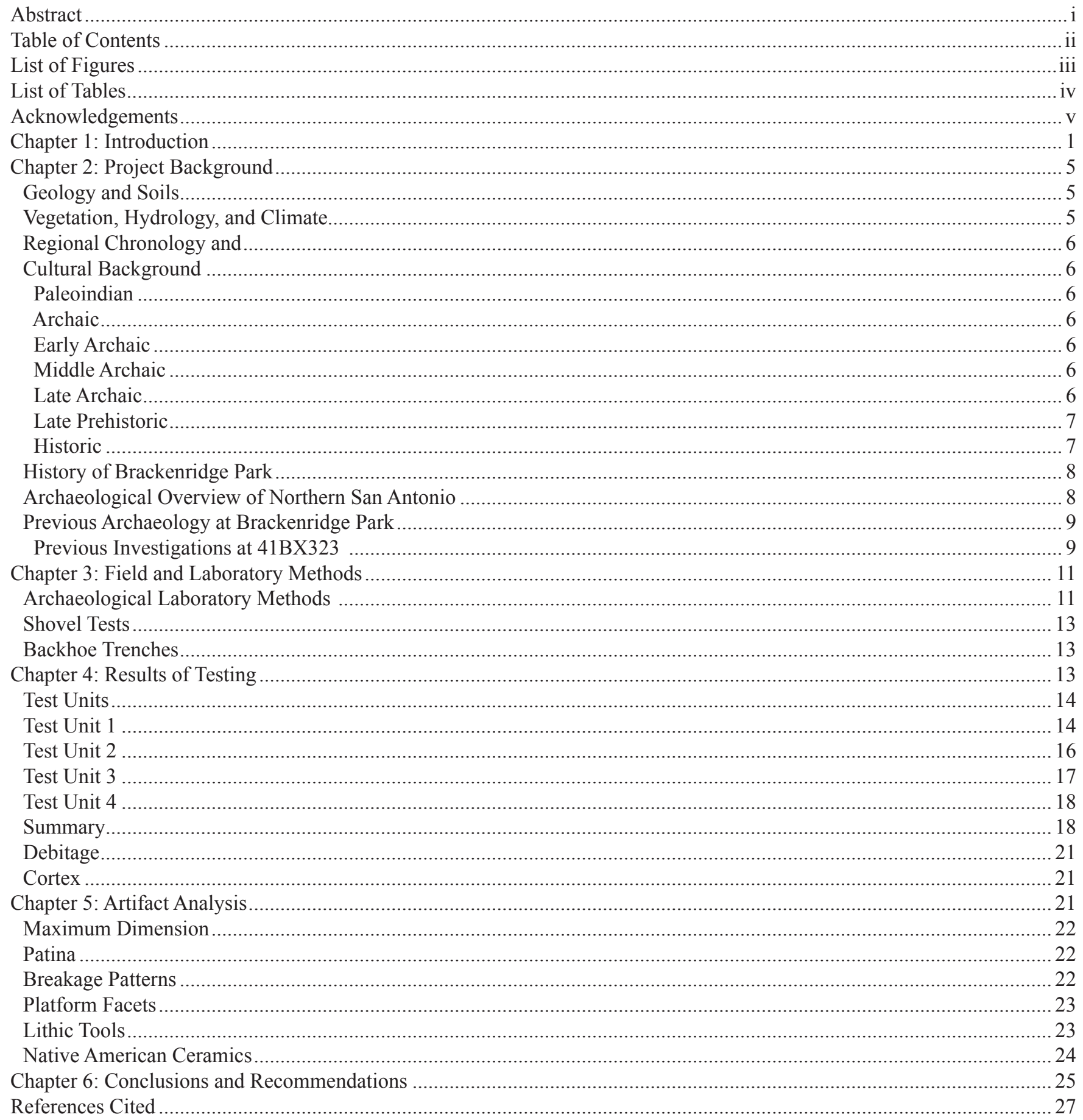




\section{List of Figures:}

Figure 1-1. The project area located in San Antonio, Bexar County, Texas......................................................................... 1

Figure 1-2. The footprint of the proposed parking garage facility and the Area of Potential Effect.......................................2

Figure 1-3. The San Antonio Zoo train tracks running through the middle of the project area............................................... 3

Figure 1-4. The San Antonio Parks and Recreation building. ........................................................................................... 3

Figure 4-1. Shovel tests, backhoe trenches, and test unit shown in relationship to the proposed footprint of the

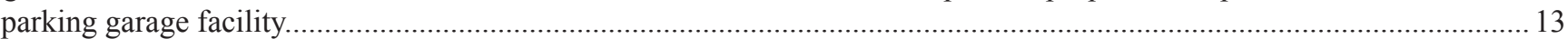

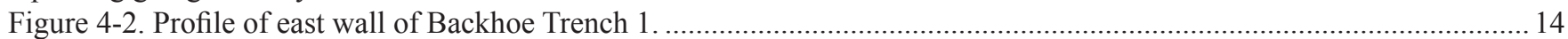

Figure 4-3. Profile of east wall of Backhoe Trench 2.

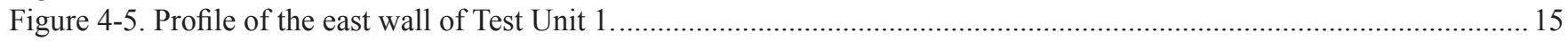

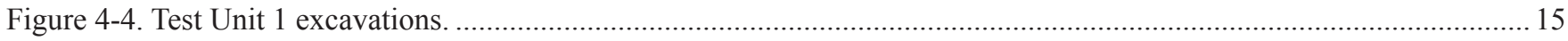

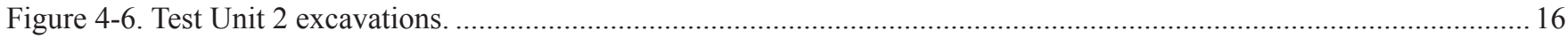

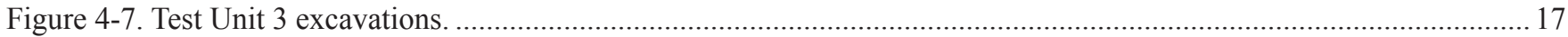

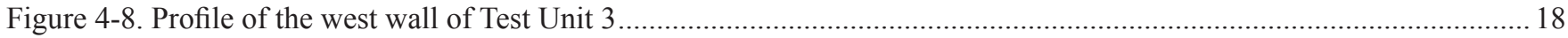

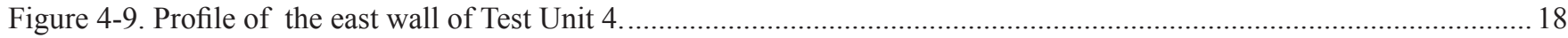

Figure 4-11. Line graph showing density of debitage and burned rock by level in the four excavated units combined........... 19

Figure 5-1. Box plot exhibiting maximum dimension of debitage by cortex percentages................................................. 22

Figure 5-2. Lithic tools from 41BX323: a-d) bifaces e) edge-modified blade .................................................................2

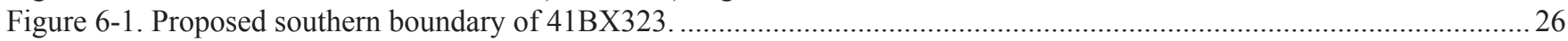




\section{List of Tables:}

Table 4-1. Cultural Material Collected from Shovel Tests

Table 4-2. Cultural Material Recovered from Test Unit 1

Table 4-3. Cultural Material Recovered from Test Unit 2

Table 4-4. Cultural Material Recovered from Test Unit 3

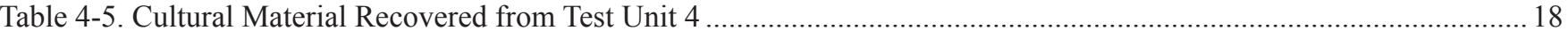

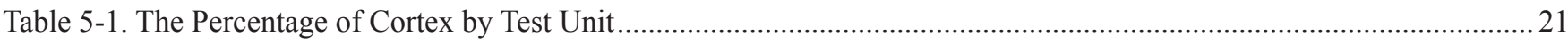

Table 5-2. Percentage of Corticate Debitage for Upper and Lower Component of 41BX323 ….......................................... 22

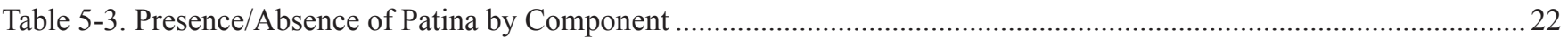

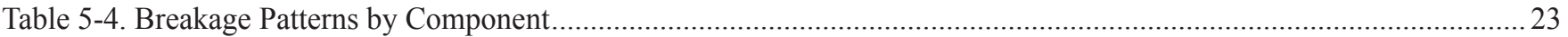

Table 5-5. Lithic Tools and Cores Recovered from Test Unit Excavations ........................................................................2 23 


\section{Acknowledgements:}

The authors would like to thank several individuals that were involved in completing this project. Special thanks to Kim Monroe from Lake/Flato Architects for helping with field logistics and report comments. The field crew consisted of Nate Devito, Cyndi Dickey, Jon Dowling, Jason Perez and Lindy Martinez. Many thanks to the San Antonio Zoo train depot staff for refreshments and their interest in the project. CESA Contractors, Inc. provided backhoe services for the field project. Lab technicians that processed the artifacts included Nate Devito and Cyndi Dickey. Nate Devito assisted with the lithic analysis. Thanks to Steve Tomka, Principal Investigator, and Raymond Maulidin for discussing analysis results and providing comments. The authors would also like to thank Bruce Moses for drafting the report figures. This report was formatted and edited by Bruce Moses. 



\section{Chapter 1: Introduction}

This report discusses the results of archaeological testing of State Archaeological Landmark site 41BX323 that occurred between September 6, 2007 and September 26, 2007. The Center for Archaeological Research at The University of Texas at San Antonio (CAR-UTSA) was contracted by Lake/Flato Architects to conduct archaeological testing on previously uninvestigated portions of 41BX323. Lake/ Flato Architects was contracted by the City of San Antonio Parks and Recreation Department to design and oversee the construction of a proposed parking garage facility. The proposed improvements will impact the southeastern portions of State Archaeological Landmark (SAL) 41BX323 located in Brackenridge Park, San Antonio, Bexar County, Texas (Figure 1-1). This project was conducted under Texas Historical Commission (THC) permit \# 4647 with Steve Tomka serving as Principal Investigator and Antonia L. Figueroa acting as Project Archaeologist.

The land impacted by the project is owned by the City of San Antonio, a political subdivision of the State of Texas. As such, the project has to comply with State Historic Preservation laws and specifically the mandates of the Antiquities Code of Texas and fall under the oversight of the Texas Historical Commission.

The primary goal of CAR's archaeological investigation was to determine if the proposed impacts would adversely affect deposits that contribute to the site's SAL eligibility. Moreover, the second goal of the investigations was to better define the southern boundary of the site. Archaeological investigations conducted by CAR resulted in the excavation twenty-shovel tests, two backhoe trenches and four 1-x-1 meter test units. The majority of recovered cultural material consisted of lithic debitage and burned rock. A small sample of ceramics was also recovered. No features were encountered during the field investigations.

This report is divided into six chapters. The project environment and previous archaeology is presented in Chapter 2. Chapter 3 includes the field and laboratory methodology used during the project and the results of field investigations are discussed in Chapter 4. Chapter 5 presents the results of the artifact analysis, while a summary and recommendations are in Chapter 6. The remainder of this chapter will discuss the project area and Area of Potential Effect (APE).

\section{The Project Area and Area of Potential Effect}

The project area is located on the south bank of the San Antonio River, south of Tuleta Drive and Avenue B intersection, adjacent to the Witte Museum. Proposed improvements to this portion of Brackenridge Park involves a parking garage facility. The footprint of the parking garage facility (Figure 1-2), the APE, measures approximately $3617 \mathrm{~m} 2(0.907$ acres). The anticipated depth of impacts for the proposed parking facility ranges from 3 feet ( 0.914 meters) to 5 feet (1.52 meters). The deepest impact will be localized in the area of the piers that will support the parking facility. Here, the impacts may reach a depth of 40 -feet (i.e. bedrock). As seen in Figure 1-3, existing parking areas and Parks and Recreation buildings are located over a large portion (approximately 35 $\%)$ of the APE. The proposed improvements will be impacting portions of SAL 41BX323. The site was identified in 1979 and details of previous archaeological work at the site are discussed in Chapter 2.

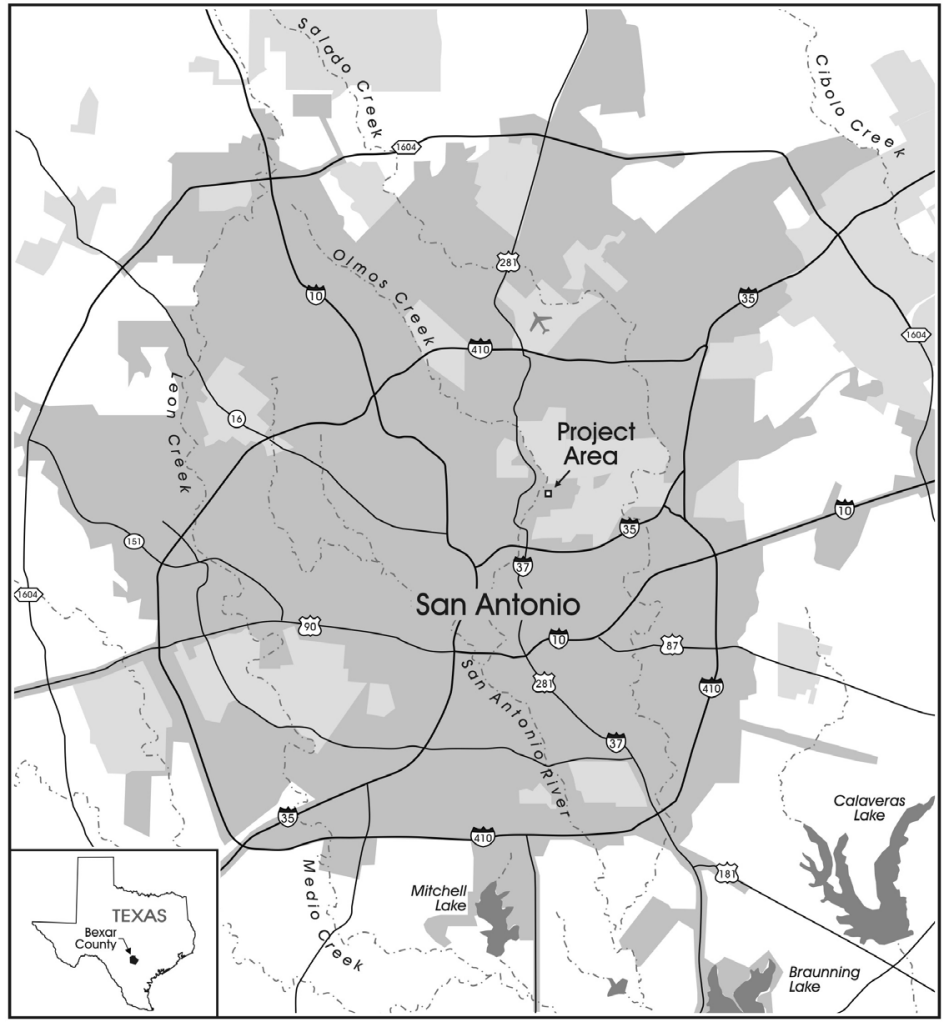

Figure 1-1. The project area located in San Antonio, Bexar County, Texas. 


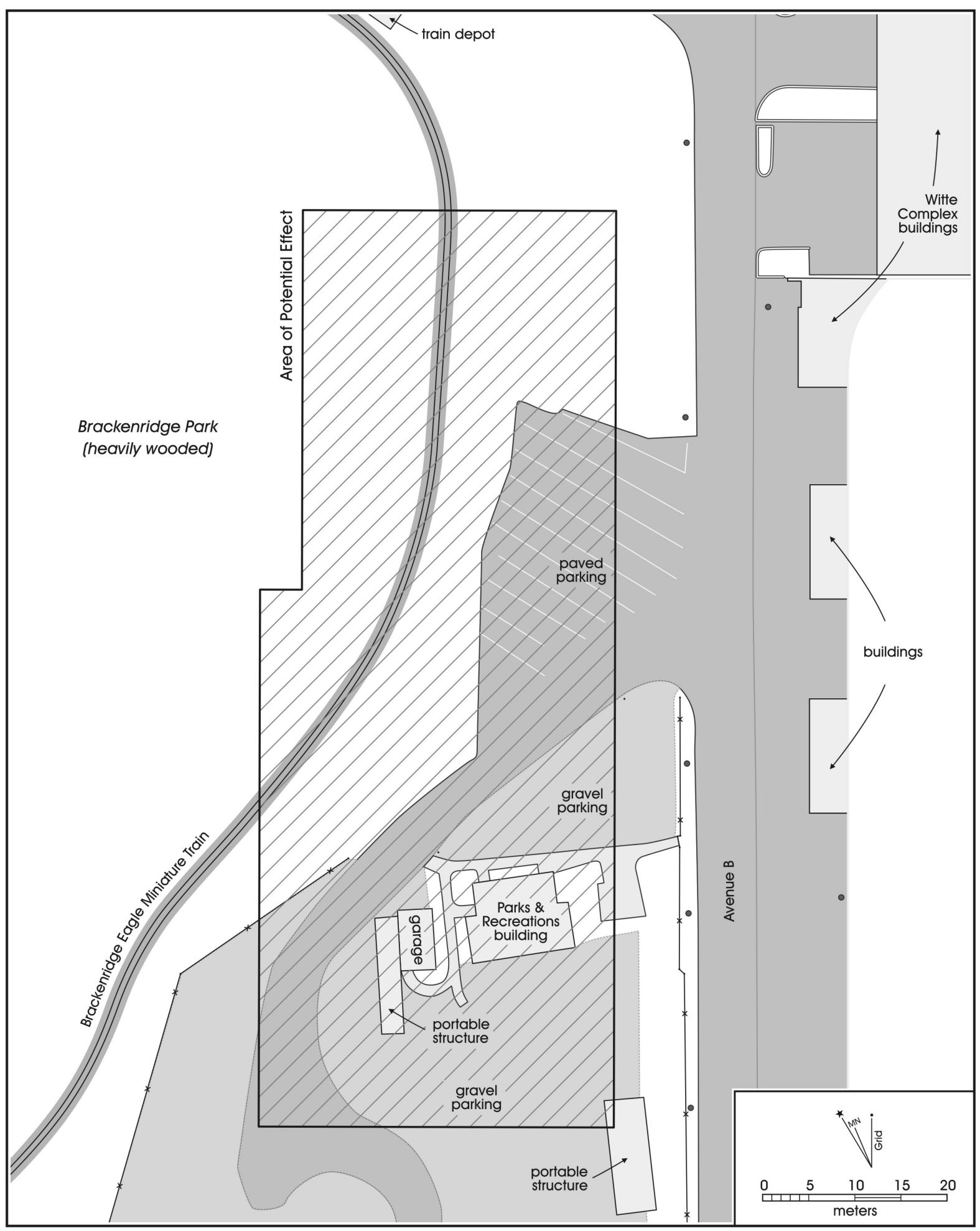

Figure 1-2. The footprint of the proposed parking garage facility and the Area of Potential Effect.

The project area is dissected by the San Antonio Zoo train tracks and the Witte train depot is located just to the north (Figure 1-3). The western portion of the project area is dominated by indigenous plant species but non-native species are also present. The eastern side of the project area has been disturbed by existing parking areas and a Parks and Recreation Department buildings (Figure 1-5 ). Bamboo lines the eastern portion of the train tracks. 


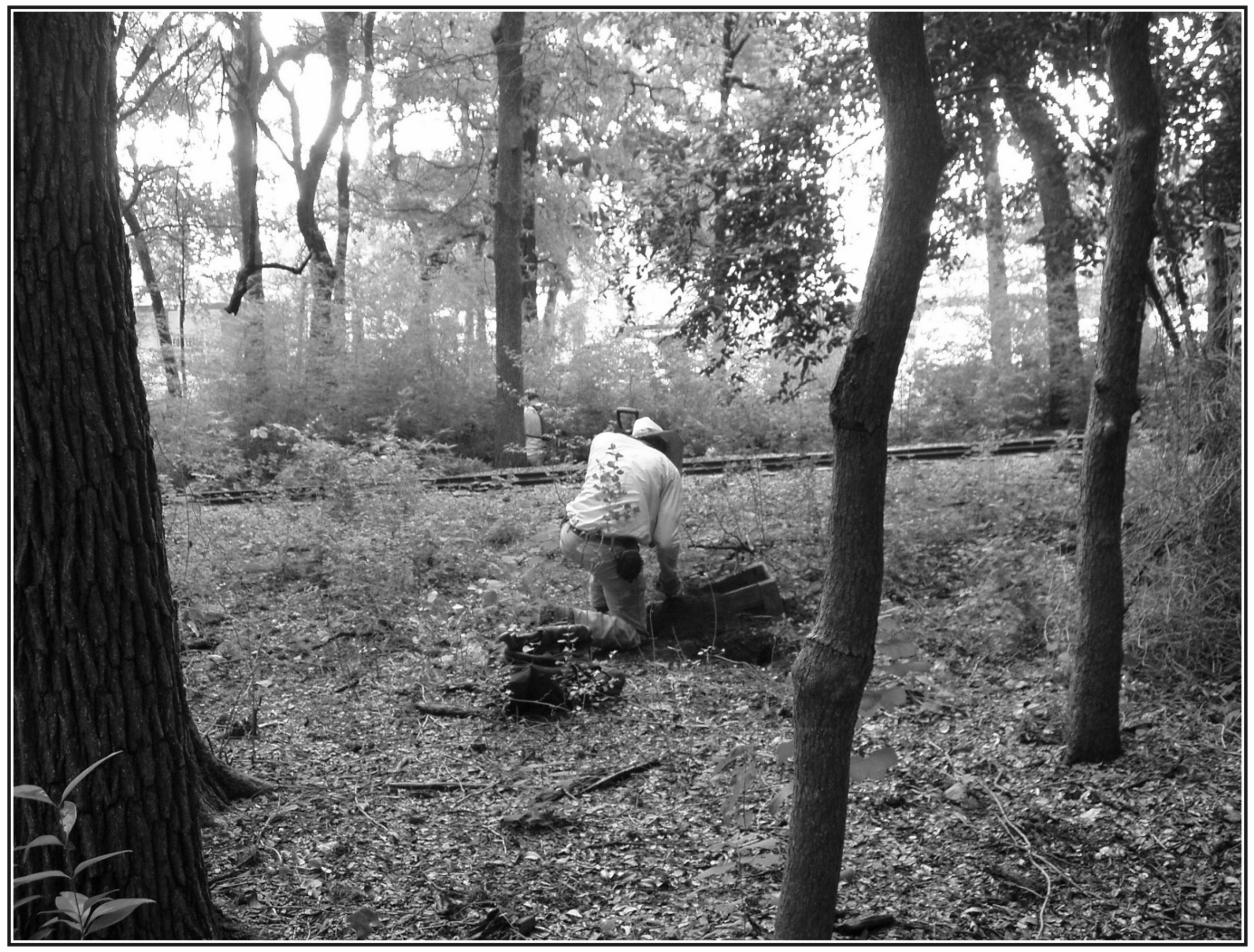

Figure 1-3. The San Antonio Zoo train tracks running through the middle of the project area.

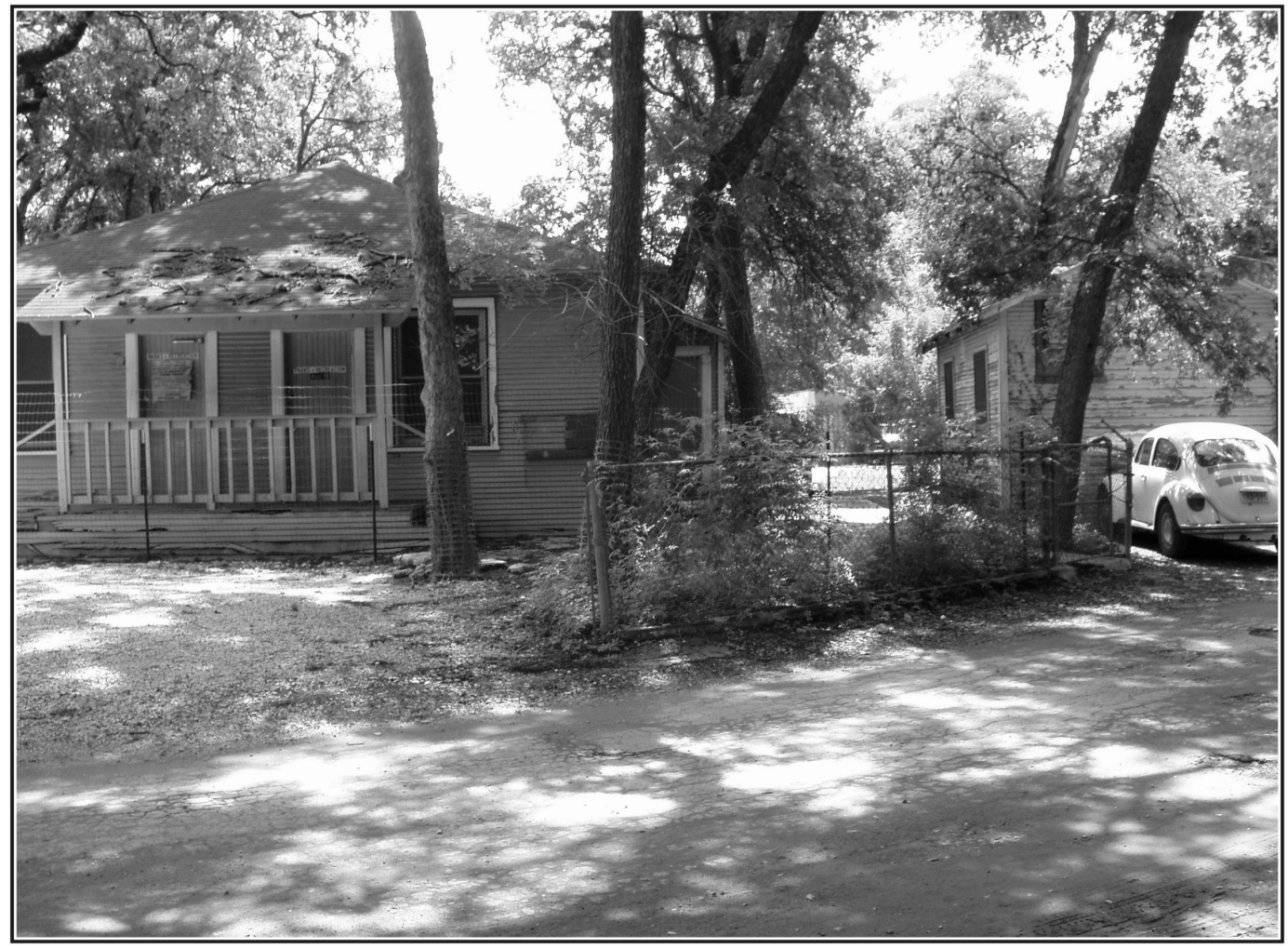

Figure 1-4. The San Antonio Parks and Recreation building. 



\section{Chapter 2: Project Background}

The environmental and cultural development of Bexar County has been greatly shaped by its position on the edge of the Edward's Plateau. This ecotone provided by the Balcones Escarpment has generated diverse biotic resources, long utilized by the prehistoric inhabitants of present-day San Antonio. Of the seven biotic provinces of Texas provided by Blair (1950:112), the San Antonio area lies on the southern edge of the Balconian Province. The proximity of two neighboring provinces, the forested Texan and the arid Tamaulipan, increase resource variability that would have been available to prehistoric inhabitants.

\section{Geology and Soils}

The surface geology of the San Antonio area is the result Miocene uplifting that produced the Edwards Plateau and Balcones Escarpment. Brackenridge Park consists of Quaternary Alluvium and Fluviatile terrace deposits, composed primarily of silts and clays overlying ancient alluvium (Barnes 1983). Skirting the northwestern section of the park is an upland projection of Austin limestone made up of marl, chalk, and limestone left by the receding sea-line of the upper Cretaceous Period. The ready sources of limestone were quarried by the Spanish in the 1700s for construction material (Spearing 1992:89). East and south of the park lay Uvalde gravels that served as important lithic raw materials for prehistoric inhabitants. Also to the east of the park is the Navarro Group and Marlbrook Marl formations comprised of sands, clays, marls, and sandstone. North of the project area, one mostly finds fine to medium grained Edwards Limestone. Within Edwards limestone, chert nodules are commonly found which served as lithic sources to prehistoric populations for more than 11,000 years (Banks 1990; Frederick and Ringstaff 1994).

Soil units within the study area are outlined by the Soil Conservation Service (Taylor et al. 1991), and consist of Trinity, Frio, and Lewisville soils that are calcareous alluvial deposits. These soils are usually found on 0-1 percent slopes on riparian terraces. Trinity and Frio soils are characterized by deep slowly permeable calcareous clays to clay loams with possible gravel layers. The substrate is alluvium, forming a deep profile of fine sediments. Lewisville soils are distinguished by their deep, dark grayish-brown to brown calcareous silty clays. The parent material of Lewisville soils are usually ancient alluvium on level to level areas on active floodplains. Profiles usually depict brown, subangular, blocky silty clays that lay over a reddish-yellow lower stratum of similar structure and texture with abundant calcium carbonate flecks and nodules.

\section{Vegetation, Hydrology, and Climate}

Since the project area is positioned in an area where the Edwards Plateau, Blackland Prairie, and South Texas Plains converge, there exists a mosaic of vegetation communities (Gould 1969). The Balcones Escarpment deviates sharply from the thin soiled limestone uplands and the wide coastal plains. Mixed live oak, Ashe juniper woodlands and sporadic grassy openings compose the bulk of upland vegetation. Tree canopy closure, for the most part, is generally low, and Ashe juniper is most prevailing in density. Texas oak and cedar elm also occur in low densities. In upland areas, shrub density varies from low to dense. Low density species include Texas persimmon, agarita, prickly pear, and mixed grasses. The Blackland Prairie and South Texas Plains have a gently rolling topography that sustains hickory, red oaks, and hackberry that accompanies an understory of poison ivy, Virginia creeper, and green briar (Gould 1969).

Numerous springs, aquifers, and rivers are interspersed in and around the Balcones Escarpment due to the hinge line faulting along the Paleozoic Ouachita structural belt (Foley and Woodruff 1986). The large underwater reservoir of the Edwards Aquifer lies in west-central Texas where water percolates through Lower Cretaceous limestone that rests on virtually impermeable pre-Cretaceous formations (Barker et al. 1994). Excellent potable water sources arise as a result of this percolation. Springs created from the Balcones Escarpment give birth to several rivers in Bexar County. Such spring-waters are fresh, alkaline in nature as well as very hard, containing primarily calcium bicarbonates (Brune 1981:70). The San Antonio Springs, just north of Brackenridge Park, is the source of the San Antonio River. Other rivers generated by the Balcones Escarpment springs include the Guadalupe, Comal, San Marcos, and Blanco rivers. Since these rivers do not rely much on rainfall as a water source and drain smaller areas than other rivers in the state, they are shorter and clearer than other rivers in Texas.

This area of Central Texas has a subhumid climate as a result of moderate rainfall and fairly warm temperatures (Bomar 1983:208-222). The annual average rainfall for San Antonio is 29.13 inches of precipitation, with the rainiest months being in May, June, and September (Bomar 1983:222). 
Precipitation in Central Texas stems from the tumultuous transition between arctic and Gulf of Mexico air masses. Average San Antonio temperatures range from 39.0-61.7 degrees Fahrenheit (January) to 74.3-94.9 degrees Fahrenheit (July).

\section{Regional Chronology and Cultural Background}

The project area is situated on the cusp of Central and South Texas. This culture history will reference primarily Central Texas regional patterns, but will also include relevant South Texas trends and developments. Once a culture chronology for this region of Texas has been reviewed, the following section will provide a brief summary of the history and intensive archaeological work carried out around the vicinity of the project area, and within.

\section{Paleoindian}

The arrival of humans in the New World occurred during the Paleoindian period which dates from 11,500-8800 BP (Collins 1995). As the Pleistocene period ended, diagnostic Paleoindian materials in the form of Clovis, Folsom, and Plainview projectile points began to enter the archaeological record. These points were lanceolate-shaped and fluted for hafting to wooden spears. Using the launching momentum from atlatls (spearthrowers), large game such as mammoth, mastodons, bison, camel, and horse were frequently taken (Black 1989). Stylistic changes in projectile point technology occurred during this later portion of the period, eventually shifting to Dalton, Scottsbluff, and Golondrina traditions. While widespread in geographic range, these types occurred in high densities in the High Plains and Central Texas (Meltzer and Bever 1995). As megafauna gradually died off and as the climate warmed, subsistence patterns shifted toward smaller game and plant foraging.

\section{Archaic}

The Archaic period, broadly divided into the Early, Middle, and Late Archaic subperiods, signifies a more intensive reliance on local floral and faunal resources with an increase in the number of projectile point styles (Collins 1995). The archaeological record begins to indicate more widespread use of burned rock middens, a wider variety of site functions, and more localized geographic distributions of these materials.

\section{Early Archaic}

Hester places the Early Archaic between 7950 and 4450 BP based on Early Corner Notched and Early Basal Notched projectile points (1995:436-438). Collins' dating of the Early Archaic period to 8800 to $6000 \mathrm{BP}$ is founded on unstemmed point types (1995:383). Around $8000 \mathrm{BP}$ styles transitioned to stemmed varieties such as the Martindale and Uvalde (Black 1989). As the extinction of megafauna herds took hold, a subsistence shift towards heavier reliance on deer, fish, and plants became necessary. In the archaeological record, this trend equates to greater densities of ground stone artifacts, fire-cracked rock midden features, and task specific tools such as Clear Fork gouges and Guadalupe and Nueces bifaces (Turner and Hester 1993:246, 256). Most Early Archaic opencampsite concentrations were distributed along the eastern and southern margins of the Edwards Plateau in areas with reliable water sources (McKinney 1981). Population densities were relatively low and consisted of small bands with a fairly high degree of mobility (Story 1985:39). Loeve-Fox, Jetta Court and Sleeper sites are all accurate representative sites of the Early Archaic (Collins 1995).

\section{Middle Archaic}

Middle Archaic materials date from about 6000 to 4000 BP, with increased occurrence of multi-use bifacial knives and burned rock middens (Collins 1995:383). Diagnostic points from this period include Bell, Andice, Taylor, Nolan, and Travis. Although the beginning of the Middle Archaic still exhibited large-game hunting of bison, the climate became much drier towards the end of the Middle Archaic necessitating a heavier reliance on sotol and acorn harvesting (Weir 1976:126). An expansion of oak woodlands on the Edwards Plateau and Balcones Escarpment may have been conducive to the intensified exploitation of certain plants (Weir 1976). This period also experienced population increases and it is possible that previously scattered bands of hunter-gatherers began to combine harvesting and processing efforts (Weir 1976:126). Panthers Spring Site, Landslide, Wounded Eye and Gibson sites demonstrate well the cultural trends of the Middle Archaic (Collins 1995).

\section{Late Archaic}

The last subperiod of the Archaic falls between 4000-800 BP (Collins 1995:384). Dart point diagnostics of the Late Archaic are somewhat smaller, triangular points with corner notches such as the Ensor and Ellis (Turner and Hester 1993:114,122). Other Late Archaic points include Bulverde, Pedernales, Marshall, and Marcos (Collins 1995). It is not entirely clear whether this period experienced a rise (Collins 
1995, Prewitt 1981) or decline (Black 1989) in population numbers, but large cemeteries, grave goods, and exotic trade items are known to occur at this time at sites such as Loma Sandia, Rudy Haiduk, Silo, Ernest Witte, Morhiss Mound in Central and South Texas. Evidence of the Thunder Valley sinkhole cemetery has suggested that territoriality may have established during the Late Archaic, possibly as a result of population increase (Bement 1989). The frequency of burned rock middens increase and open campsites appears to increase. Characteristic Late Archaic sites include the Anthon and Loeve Fox sites (Collins 1995).

\section{Late Prehistoric}

There exists some degree of overlap between diagnostic tools that are considered Late Archaic and Late Prehistoric, but the commonly held date for the beginning of this interval is 1200 BP. A hallmark transition for this period is the introduction of the bow and arrow that enabled prehistoric hunters to harvest prey from greater distances with a lesser need for brushless, wide open spaces required for atlatl maneuverability in hunting. The use of arrows is indicated by much smaller sized projectile points like the Perdiz and Scallorn. Another turning point in the Late Prehistoric period is the first substantial presence of pottery in the northern South Texas Plain and Central Texas (Black 1989, Story 1985). Researchers generally agree that during this period there was a drop in population (Black 1989). Inter-group conflicts between various bands of hunter gatherers may have also been an issue based on evidence of arrow inflicted deaths seen in human remains from various Late Prehistoric cemeteries. Sites with distinct Late Prehistoric components include the Kyle, Smith and Currie sites (Collins 1995). Interval divisions for this period are the Austin and Toyah phases. Johnson (1994) believes these phases to possibly be two distinct cultures (see Black and Creel 1997).

The Austin Phase of the Late Prehistoric may demonstrate the most intensive use of burned rock middens (Black and Creel 1997), and includes diagnostic point types Scallorn and Edwards (Collins 1995; Turner and Hester 1993). During this phase, the use of burned rock middens is still quite widespread and may even be on the rise (Mauldin and Nickels 2003). The Toyah subperiod of the Late Prehistoric suggests interaction between Central Texas and ceramic producing traditions in East and North Texas due to the presence of bone-tempered plainware ceramics (Pertulla et al. 1995). Ceramics were in common usage in East Texas by $2450 \mathrm{BP}$, but the first Central Texas plainwares did not appear until ca. 650/700 BP. Other technological traits of this phase include the diagnostic Perdiz point, alternately beveled bifaces, and specialized processing kits as an adaption to flourishing bison populations (Ricklis 1992).

\section{Historic}

Since the lateA.D. 1500s, Europeans entered South and Central Texas only sporadically and did not settle there until around A.D. 1700 (Webb 1952). First European contact on the Texas coast most likely began with the landing of Cabeza de Vaca and the Narvaez expedition survivors in 1528. Later Spanish incursions recorded insightful information on various Native American tribes like the Payaya, collectively referred to as the Coahuiltecans, who at one point lived in the area around modern day San Antonio. Late seventeenth century accounts describe these people as family units of hunter gatherers that resided near streams and springs, in areas conducive to nut harvesting. These camps were revisited on a seasonal basis, allowing interaction with different groups along the way as well as the hunting of bison in open grassland settings (Campbell 1983:349-351, Hester 1989:80). By the eighteenth century, the cultural integrity of the Coahuiltecans was significantly compromised by European settlers and invasive neighboring Native American groups, such as the Tonkawa and the Lipan Apache, made possible through access to European horses. Efficiently skilled Comanche horsemen in turn displaced the Lipan Apache culture, effectuating continuous raids on European and Native American settlements alike in Central Texas (Hester 1989:82-83).

In response to the continuous threat of Apache and Comanche raiders and the French incursion into East Texas, a series of Spanish missions and presidios were erected along the San Antonio River during the eighteenth century. The Spanish governor of Coahuila and Texas, as well as the captaingeneral, Joseph de Azlor y Virto de Vera, Marques de San Miguel de Aguayo established San Antonio as the focus of European settlement (Cox 1997).

From its establishment around 1718, San Antonio gradually became a somewhat developed provincial town. In 1821, Spain lost several continental territories when it recognized the independence of Mexico. At this time, San Antonio mostly consisted of a group of flat-roofed stone and adobe buildings centered around Main and Military Plazas. Eventually, the newly independent Mexican government began granting impresario contracts to allow more prominent Anglo settlement to facilitate the town's development. Stephen F. Austin, one such settler, spearheaded a movement by Anglo and Mexican settlers against Mexican authority towards independence. As a sort of crossroads location, San Antonio de Bexar played an integral role in Texas Independence. At its center stood Mission San Antonio de Valero (the Alamo), which brandished more cannons than any fort west of the Mississippi and changed hands several times during the fight for Texas Independence, falling victim to Mexican siege in 1836 . So many battles took a terrible toll in lives 
and property, leaving San Antonio nearly deserted for some time (Fox 1979). After becoming the Republic of Texas the same year, following the decisive Battle at San Jacinto, the territory later joined the United States in 1845. The town slowly grew from a rustic Mexican Village to a lively and fast-paced commercial center. Still a major crossroads, San Antonio served as a key staging area for General Zachary Taylor's mobilization efforts during the War with Mexico. During the American Civil War, the Confederate state of Texas was only involved in five engagements with the Union army. San Antonio's main function during the Civil war was that of a shipping hub for supplies imported from Mexico to be shipped to Confederate lines in the early 1860s (Webb 1952). The town also suffered a major cholera epidemic in 1866.

\section{History of Brackenridge Park}

Brackenridge Park encompasses close to 320 acres, some of which were part of the original land grant to the City of San Antonio. While it was under Spanish ownership, two major acequias channeled water to early settlements between the San Antonio River and San Pedro Creek (Cox et al. 1999). Relying on gravity flow, these channels are still visible on the landscape today. The "Upper Labor Ditch" acequia, completed in 1778 , still operates, carrying water to animal exhibits in the zoological gardens. The Upper Labor's original Spanish Colonial Dam had to be relocated during archaeological investigations in 1996 on Hilderbrandt Avenue. This dam was composed of undressed, Colonial limestone that was augmented sometime in the nineteenth century by German masons using ashlar-dressed stones. During the 1700s, the second acequia called the "Alamo Madre Acequia" was built to provide water to Mission de Valero. The diversion dam is still present in the San Antonio River just north of the Witte Museum. After primarily serving as a water source for the city, the northwest area of the park then became a quarry for limestone and mortar production. Just southeast of this area existed a mercado that drew city residents to this area regularly for various types of commerce (Brackenridge Park files at the San Antonio Public Library).

During the American Civil War in 1863, the area of Brackenridge Park changed hands from the city to the Confederate States of America for $\$ 5,000$ to establish a tannery. Upon conclusion of the Civil War, ownership of the land went to Bureau of Refugees, Freed men, and Abandoned Lands of the United States Government. In 1868, this tract of land was sold back to the City of San Antonio for $\$ 4,500$. In 1874 , the area where the tannery was established was subdivided into Koehler Park, Allison Park, and the polo field area after a series of auctions. One of the winning bidders was George W. Brackenridge, a major shareholder in the San Antonio Waterworks Company (Brackenridge Park Files at City of San Antonio Historic Preservation Office).

Numerous waterworks facilities were established by the San Antonio Waterworks Company to pump water to an elevated reservoir in the area where the Botanical Gardens are currently situated (North San Antonio Times, March 29, 1979). In the late 1800 s a great deal of progress including a cement company, a horse track, an iron bridge over the San Antonio River, a golf course clubhouse, and a rodeo corral also used by the Sheriff's Dept. was developed (Brackenridge Park Files at City of San Antonio Historic Preservation Office).

In 1899, George W. Brackenridge contributed a generous tract of this land to the City of San Antonio that included almost all park land east of the San Antonio River, west of the river, and south of Craig Avenue. Brackenridge's stipulated under contract that the land was to be used as a public park (Bexar County Deed Records, Vol. 185:183-188). Development soon gave rise to the botanical and zoological gardens, a series of access roads, and picnicking areas. A donkey barn for tours of the park was eventually remodeled into a Parks and Recreation Administrative Office. In 1912, the Zoological Gardens began development, with a donation of bison and elk herds from George W. Brackenridge, and the project eventually grew to become the San Antonio Zoo (Brackenridge Park Files at City of San Antonio Historic Preservation Office).

The Sunken Gardens were created in a limestone quarry area by prison labor in 1919. Originally dubbed the "Japanese Tea Garden", the Japanese proprietors were forced out of business and relocated to a concentration camp during World War II (Brackenridge Park Files at San Antonio Public Library). The Works Progress Administration built the Sunken Garden for the San Antonio Civic Opera Association in the 1930s, and also stone-lined portions of the San Antonio River. Following that, the Witte Museum and numerous public facilities were erected in the immediate vicinity, such as the Joske and Koehler pavilions and several memorial monuments to the Brackenridge family (Brackenridge Park Files at City of San Antonio Historic Preservation Office).

\section{Archaeological Overview of Northern San Antonio}

The archaeological investigations conducted in this area have been fairly extensive. Since the 1930s, northern San Antonio has yielded significant prehistoric and historic cultural materials. Sites in the vicinity of San Antonio Springs 
and Olmos Dam yielded Paleoindian artifacts, surface hearths, and bone beds (Orchard and Campbell 1954). A Paleoindian occupation also occurred at the St. Mary's Hall Site (41BX229) along Salado Creek. The integrity of these sites was compromised by a fair amount of looting, but the Center for Archaeological Research (CAR) at the University of Texas at San Antonio (UTSA) and the Southern Texas Archaeological Association (STAA) were able to recover a good deal of material in 1977. Plainview and Angostura projectile points were collected suggesting a late Paleoindian occupation, but this assessment may be revised after a regional comparison of like points with differing contextual data (Hester 1978, 1990, 1995). South of that location rests the Granberg site (41BX271), investigated in the 1970s by CAR, and revisited in 2005 (Thompson 2006). The Pavo Real site (41BX52), along Leon Creek, contained Clovis and Folsom components in undisturbed contexts (Collins et al. 2003; Henderson and Goode 1991).

In 1975, the Walker Ranch National Archeological District was registered on the National Register of Historic Places, and included several sites. Investigated by the Texas Historical Commission (THC) and CAR, it included 41BX180, 41BX184, 41BX197, 41BX222, 41BX223, 41BX228, and 41BX996 (Potter and Black 1995:17-21). Some of the sites produced complete yet mixed archaeological records of the Paleoindian, Archaic, and Late Prehistoric periods (Black and McGraw 1985:272). Some of the sites were revisited several times over the years, and were investigated most recently by the Texas Archaeological Research Laboratory (TARL) for the Wurzbach Parkway Project (Black et al. 1998; Potter et al. 1995; Potter and Black 1995).

Another cluster of sites registered with the NRHP, is the Source of the River Archeological District containing 13 historic and prehistoric sites. In the late 1970s and early 1980s, Incarnate Word personnel recovered Early Archaic to Late Prehistoric diagnostic artifacts and documented several Historic structures (Katz and Katz 1982; Stothert 1989:40 and 68). Many of the deposits were shallow and preservation was generally poor.

\section{Previous Archaeology at Brackenridge Park}

Archaeological work conducted at Brackenridge Park was carried out by CAR and TARL in the late 1970s during two main projects. CAR staff surveyed the park grounds to document all prehistoric and historic sites within its boundaries. The staff recorded four prehistoric sites, eleven collecting localities, and 27 historic sites/features (Katz and Fox 1979). Historic features/sites consisted of several of the above mentioned water control features (Spanish acequias and historic canals), industrial features (limestone quarries and lime kilns), and recreational features (Katz and Fox 1979:12). The Spanish Alamo Madre, Upper Labor Acequias, and the Water Works and Second Waterworks canals and buildings were all recorded and researched thoroughly (Katz and Fox 1979:12). Also investigated were the Garza Mill, Old Lime Kiln, Confederate Tannery, and several industrially oriented sites geared towards limestone quarrying. Recreational features included the San Antonio Jockey Club, Joske and Koehler Pavillions, the Sunken Gardens, the Rodriguez Structures, and the Municipal Zoo. The two most significant prehistoric sites, 41BX264 and 41BX323 located adjacent to the San Antonio River, contained numerous lithic artifacts and burned rocks. 41BX264, the Polo Field site, yielded Pedernales, Nolan, and Castroville points with numerous faunal remains, lithic debris, and hearth features (Katz and Fox 1979:7).

\section{Previous Investigations at $41 \mathrm{BX} 323$}

Several archaeological investigations have been conducted at $41 \mathrm{BX} 323$ by CAR, TARL and SWCA. According to the Texas Site Altas (THC 2007), the site was deemed a SAL in 2000. 41BX323 was first identified in 1979 (Katz and Fox 1979) by CAR. At the time of the survey further work was recommended at the site. TARL conducted archaeological testing for the Witte Museum H.E.B. Science Tree house on the eastern portion of 41BX323 (Meskill and Frederick 1998). During these investigations prehistoric artifacts were recovered from 75 centimeters below surface $(\mathrm{cmbs})$. Subsequent data recovery efforts were conducted by TARL prior to the construction of the H. E. B. Tree house (Meskill et al. 2000). During the excavation of twenty-three test units, three Archaic period features were identified. Results of the archaeological investigations indicated that the site had been impacted by natural erosion and bioturbation. Investigators concluded that archaeological deposits provided information about the utilization of the San Antonio drainage system during the Archaic period (Meskill et al. 2000).

SWCA performed archaeological investigations at the site in 1998 (Miller et al. 1999). These investigations included backhoe trenching and test unit excavations. Burned rock features, a few ceramics, chipped stone and lithic tools were found to be distributed across the site. The results of excavations indicated that Early Archaic and Late Prehistoric materials were compressed within the first meter of the site's deposits. Miller et al. (1999) determined that 41BX323 was potentially eligible for listing as a State Archaeological Landmark (SAL) and recommended avoidance or mitigation. 
During the same year, data recovery was conducted by SWCA, based on recommendation from previous investigations (Miller et al. 1999), to mitigate impacts to the site from the installation of a SAWS pipeline (Houk et al. 1999). These efforts were conducted on the western half of the site and other areas. Investigations revealed cultural material and deposits that appeared to date to the Archaic and Late Prehistoric periods. Furthermore, compression and bioturbation had affected the integrity of the deposits. It was thought that the western portion of the site appeared to contain a higher potential for data recovery then the eastern portion (on the T2 terrace; Houk et al. 1999:i). Mitigation efforts concluded that site dated primarily to the Middle Archaic with lesser occupation in the Late and Transitional Archaic. Evidence of Late Prehistoric occupation was found in some areas of the site. Burned rock features dated primarily to the Middle Archaic component.

A geomorphical study by Lee Nordt (1999) was also conducted at the time of the data recovery efforts (Houk et al. 1999). He concluded that there are two terrace landforms (T1 and T2) in the site area. The T1 surface ranges from 0.5 to 1.5 $\mathrm{m}$ above the water level of the San Antonio River, while the T2 terrace is 1.5 to 2.5 meters above the current water level (Nordt 1999:49-56). According to Nordt (1999), the T2 terrace occurs in the southern and eastern portion of 41BX323. Four stratigraphic units were also identified in association with the terrace landforms; Unit 1 was the oldest of the units, while Unit 4 was the youngest. Nordt (1999) concluded that Unit 2 was associated with the early Holocene. The lower part of Unit 3 dated to the Middle and Late Arcahic periods, while the upper portions date to the Late Prehistoric. Previous investigations found no separation between the later Archaic components, possibly due to mixture and compression. Early Archaic deposits were found to be of lower integrity and impacted by park and river development (Houk et. al 1999).

In 2001, SWCA conducted auger testing (Houk and Miller 2001) and test unit excavations as part of the Brackenridge Park Rehabilitation Project Survey (Houk 2002). Auger testing confirmed that intact deposits were located on the western portion of the site. During testing, two features were encountered, one dating to the Late Prehistoric period. It was concluded from testing that the Late Prehistoric component at the site may be stratigraphically separated from older, underlying components (Houk 2002). It was suggested that Late Prehistoric materials may be better preserved south of Tuleta Drive, where minimal park development and erosion has occurred. 


\section{Chapter 3: Field and Laboratory Methods}

Testing at 41BX323 included shovel testing, backhoe trenches and test unit excavations. Shovel testing was conducted first within the APE to locate features or artifact concentrations. A portion of the APE could not be investigated due to the existing parking lot and buildings. The shovel tests were excavated at 10 meter intervals. They were $30 \mathrm{~cm}$ in diameter and extended to a maximum depth of 60 centimeters below surface (cmbs), unless otherwise prevented. The shovel tests were excavated in 10 centimeter increments and all soil was screened though a $1 / 4$-inch hardware cloth. Information was recorded on a standardized form. All cultural material was collected and brought back to the CAR laboratory for analysis.

After shovel testing, two backhoe trenches were excavated to determine the presence/absence of deeply buried deposits within the APE. Backhoe trenches were excavated, 5 meters long, about 1 meter wide and 1.5 meters deep. Back dirt and trench walls were inspected for cultural material. Profiles of the stratigraphy, including a description of soil types, were drawn for each backhoe trench.

Based on results of shovel testing and backhoe trenching, CAR excavated four 1-x-1 meter units. The test units were placed within the vicinity of positive shovel tests. All test units were orientated true north and arbitrary datums were set for each unit. The 1-x-1 meter units were excavated in 10-cm levels by hand and all matrix was screened though $1 / 4$ " hardware cloth. All cultural material was collected and bagged by level. Appropriate unit level forms were be maintained for each unit. The project archaeologist inspected the walls of the excavated units. Selected unit walls were profiled and appropriate notes and digital photographs were taken.

\section{Archaeological Laboratory Methods}

All archaeological materials recovered during testing were fully analyzed, described, and reported. All cultural materials and records obtained and/or generated during the project were prepared in accordance with federal regulation 36 CFR part 79, and THC requirements for State Held-in- Trust collections. Artifacts processed in the CAR laboratory were washed, air-dried, and stored in 4-mm zip locking archivalquality bags. Organic materials and materials needing extra support were double-bagged. Acid-free labels were placed in all artifact bags. Each label contained provenience information and a corresponding lot number written in archival ink, with pencil or laser printed. Tools and ceramics were labeled with permanent ink over a clear coat of acrylic and covered by another acrylic coat. Artifacts were separated by class and stored in acid free boxes. Digital photographs were printed on acid free paper and labeled with archivally appropriate materials and placed in archival-quality sleeves. All field forms were completed with pencil. 



\section{Chapter 4: Results of Testing}

This chapter presents the results of archaeological investigations at 41BX323. Archaeological investigations consisted of shovel testing, backhoe trenching and test unit excavations. All testing was performed within the accessible proposed footprint of the parking garage facility. Shovel test results indicated the presence of prehistoric cultural material between 0-60 (cmbs). The two backhoe trenches excavated during the project did not yield cultural material, with the exception of modern bottle glass. The excavation of four 1-x-1 meter test units yielded lithic debitage, ceramics, and burned rock.

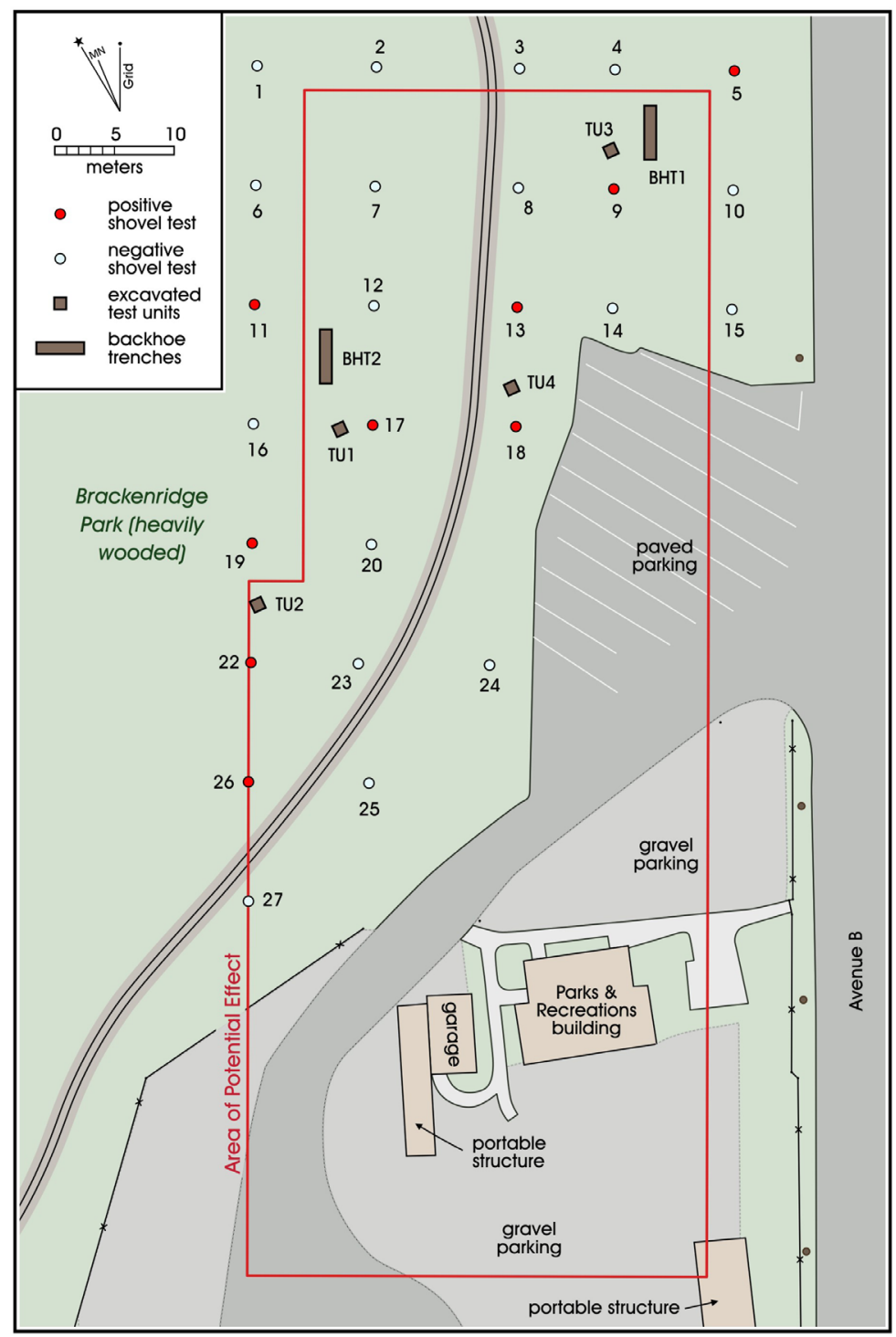

Figure 4-1. Shovel tests, backhoe trenches, and test unit shown in relationship to the proposed footprint of the parking garage facility.

\section{Shovel Tests}

Shovel tests $(\mathrm{n}=27)$ were excavated on a ten meter grid within APE (Figure 4-1). The original SOW proposed fifty-six shovel tests but due to the existing parking areas and Park and Recreation buildings twenty-nine shovel test were eliminated. Only nine (34\%) of the twenty-nine shovel tests were positive for prehistoric cultural material (Table 4-1). Positive shovel tests tend to concentrate a northeast to southwesterly line across the center of the APE. During shovel testing cultural material was recovered from between 0-60 centimeters below surface (cmbs). Artifacts consisted of lithic debitage $(n=6)$ and burned rock $(n=8)$. In the positive shovel tests, cultural materials are patterned in two clusters; one in Levels 2-3 and the other in Levels 5-6. Soils consisted of a black (10 YR 2/1) silty clay matrix with an overwhelming presence of roots. Forty percent of the positive shovel tests contained modern trash, including beer bottle glass, metal hardware and plastic. Two of these shovel tests contained modern trash as deep as Levels 5 and 6 (not collected).

\section{Backhoe Trenches}

Two backhoe trenches were excavated in the APE (see Figure 4-1). Backhoe Trench 1 was located between Shovel Tests 5 and 9, just east of the San Antonio Train tracks. The trench was roughly 5 meters long, 1 meter wide and 1.5 meters deep. A profile of the east wall of the backhoe trench was drawn (Figure 4-2). Roots were abundant in Zone 1 of the trench profile within a silty clay matrix (10YR 2/1). Zone 2 only differed

Table 4-1. Cultural Material Collected from Shovel Tests

\begin{tabular}{|c|c|c|c|c|}
\hline & Level & Burned Rock & Debitage & Total \\
\hline ST 05 & 5 & 1 & 0 & 1 \\
\hline ST 09 & 1 & 1 & 0 & 1 \\
\hline \multirow{2}{*}{ ST 11} & 1 & 0 & 1 & 1 \\
\hline & 2 & 0 & 1 & 1 \\
\hline ST 13 & 5 & 1 & 0 & 1 \\
\hline ST 17 & 3 & 2 & 0 & 2 \\
\hline ST 18 & 4 & 1 & 0 & 1 \\
\hline ST 19 & 2 & 2 & 0 & 2 \\
\hline \multirow{2}{*}{ ST 22} & 3 & 0 & 1 & 1 \\
\hline & 6 & 0 & 2 & 2 \\
\hline ST 26 & 2 & 0 & 1 & 1 \\
\hline \multicolumn{2}{|c|}{ Total } & 8 & 6 & 14 \\
\hline
\end{tabular}




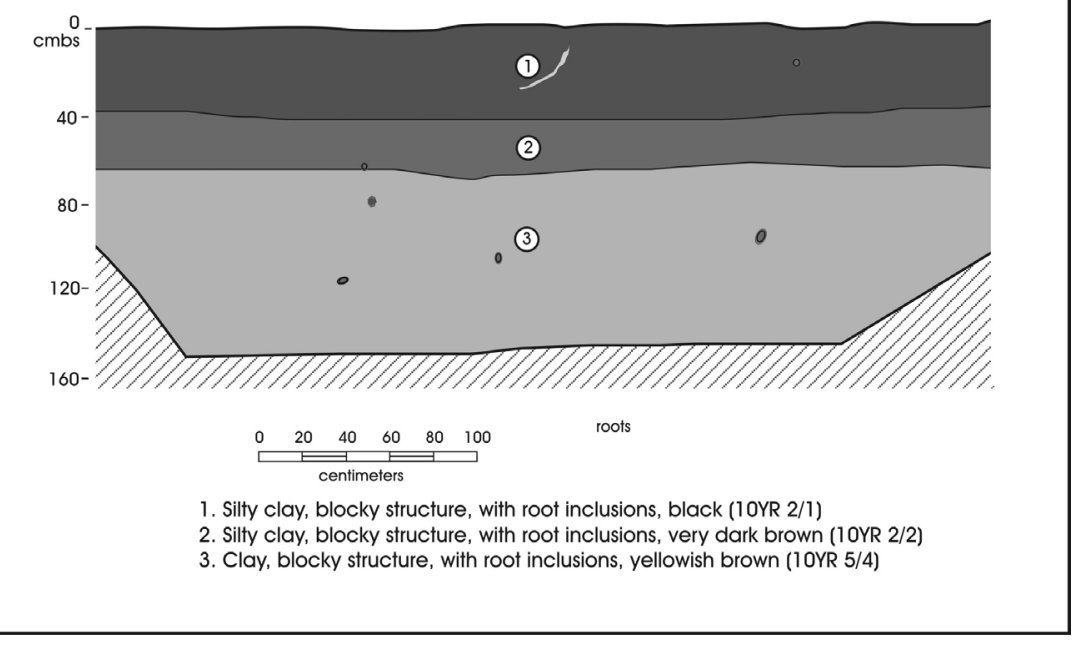

Figure 4-2. Profile of east wall of Backhoe Trench 1.

slightly in color from Zone 1 and consisted of a black (10YR $2 / 1$ ) silty clay. Roots were still present in this zone as well. Zone 3 was a yellowish brown (10YR 5/4) clay matrix with root inclusions. The only cultural material seen in the profile consisted of two pieces of clear bottle glass (see Figure 4-2); otherwise, no other culture material was recovered or seen in the backhoe trench or backdirt. ceramics, lithic tools and cores. No features were identified during test unit excavations but rather burned rock was found scattered throughout unit levels and composed of burned limestone and chert. The only faunal material was recovered from Test Unit 1 and Test Unit 4.

\section{Test Unit 1}

Test Unit 1 was located one meter northwest of Shovel Test 17 (Figure 4-4). The datum of for the test unit was set $50 \mathrm{~cm}$ from the southwest corner of the unit at $10 \mathrm{~cm}$ above ground surface. The unit was excavated eleven levels to 120 centimeters below datum (cmbd). The unit exhibited four soil zones. Figure 4-5 depicts the profile of the east wall of the test unit. Zone 1 was a black (10YR 2/1) silty clay encountered in Levels 1 through 6 . Large roots dominated the western portion of the unit through Level 6. Zone 2 consisted of a black (10YR 2/1) silty clay mottled with a brownish yellow (10YR 6/6) sandy clay. It contained fewer roots than Zone 1 and $<5 \%$ calcium carbonates ( $\mathrm{CaCO} 3$ ). Zone 3 soil was a yellowish brown (10YR 5/4) sandy clay with $>5 \% \mathrm{CaCO} 3$, while Zone 4 consisted of the same soil
Backhoe Trench 2 was located west of the train tracks where vegetation was denser. The backhoe trench was excavated between Shovel Tests 11 and 17. The trench measured 5 meters long, 1 meter wide and 1.5 meters deep. The matrix observed in this trench differed slightly from Backhoe Trench 1. Figure 4-3 is the profile of east wall of the backhoe trench. Zone 1 consisted of a black silty clay (10YR 2/1) with abundant roots. The second zone was a black (10YR 2/1) silty clay mottled with a brownish yellow (10YR 6/6) sandy clay with $5 \%$ calcium carbonate $(\mathrm{CaCO} 3)$ inclusions. Zone 3 consisted of a brownish yellow (10YR 6/6) sandy clay with $20 \% \mathrm{CaCO} 3$ inclusions. No prehistoric cultural material was observed in the trench walls or backdirt.

\section{Test Units}

Four 1-X-1 meter units were excavated as part of the testing of 41BX323 (see Figure 4-1). A total of 4.11 $\mathrm{m} 3$ of soil was removed and screened during test unit excavations. Test Units 1 and 2 were placed west of the train tracks, while Test Units 3 and 4 were east of the tracks. Cultural material recovered from the test units consisted of burned rock, debitage, Native American

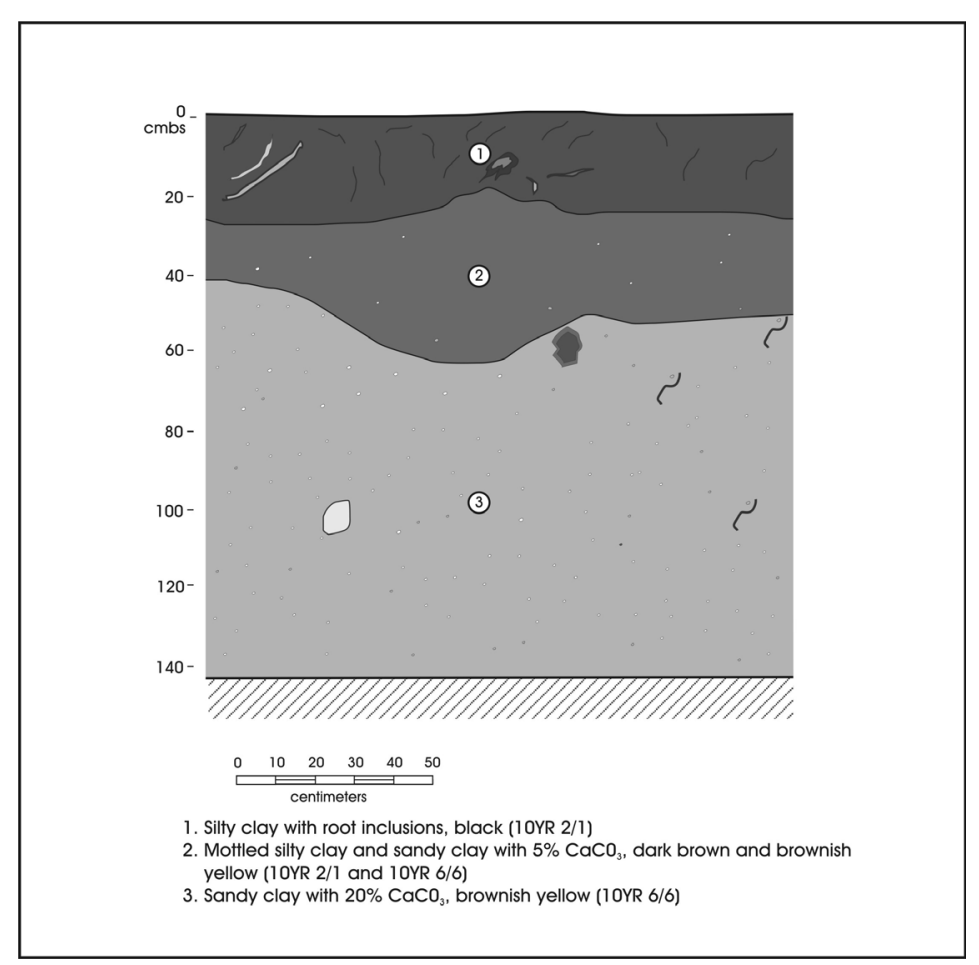

Figure 4-3. Profile of east wall of Backhoe Trench 2. 


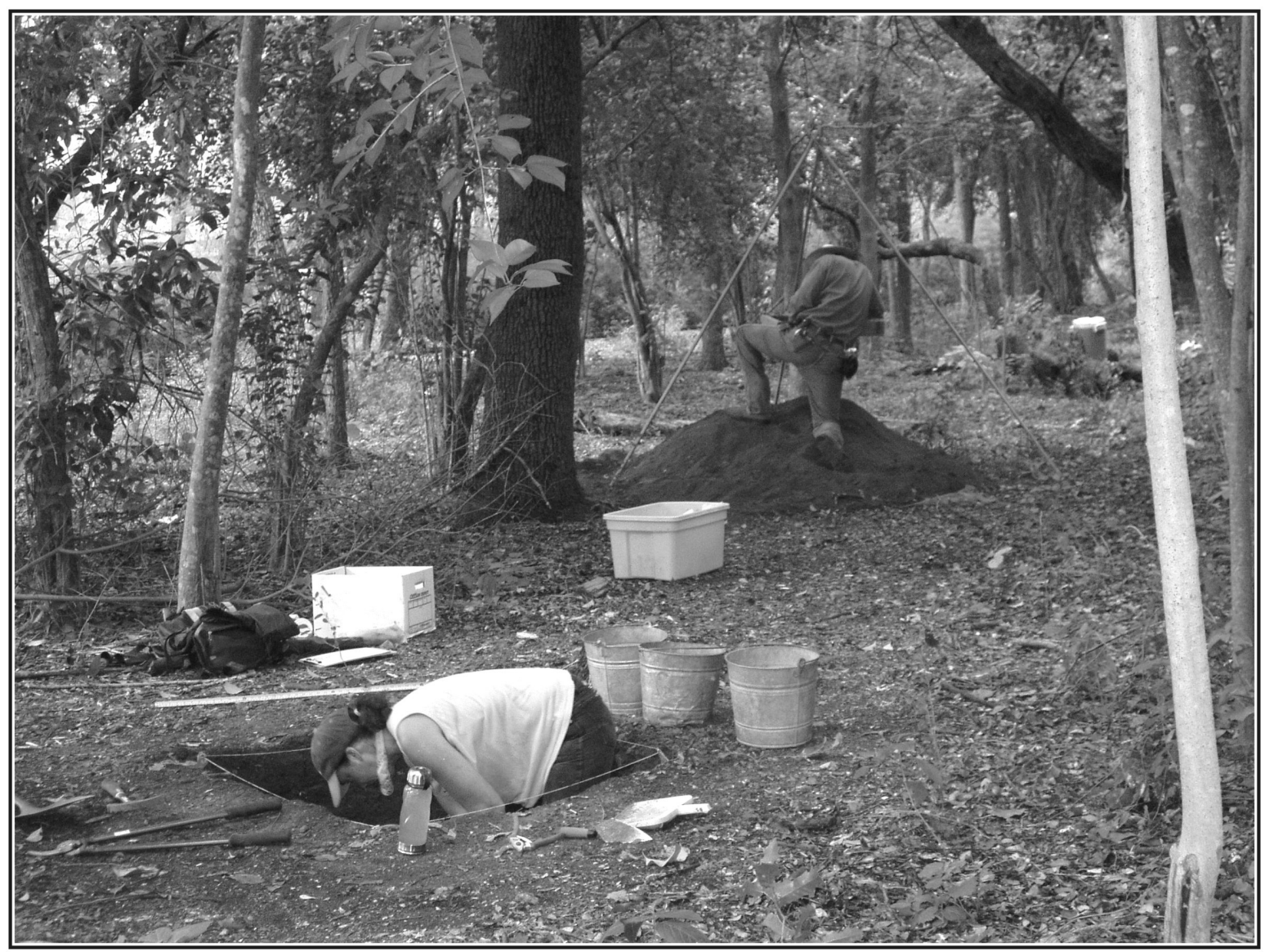

Figure 4-4. Test Unit 1 excavations.

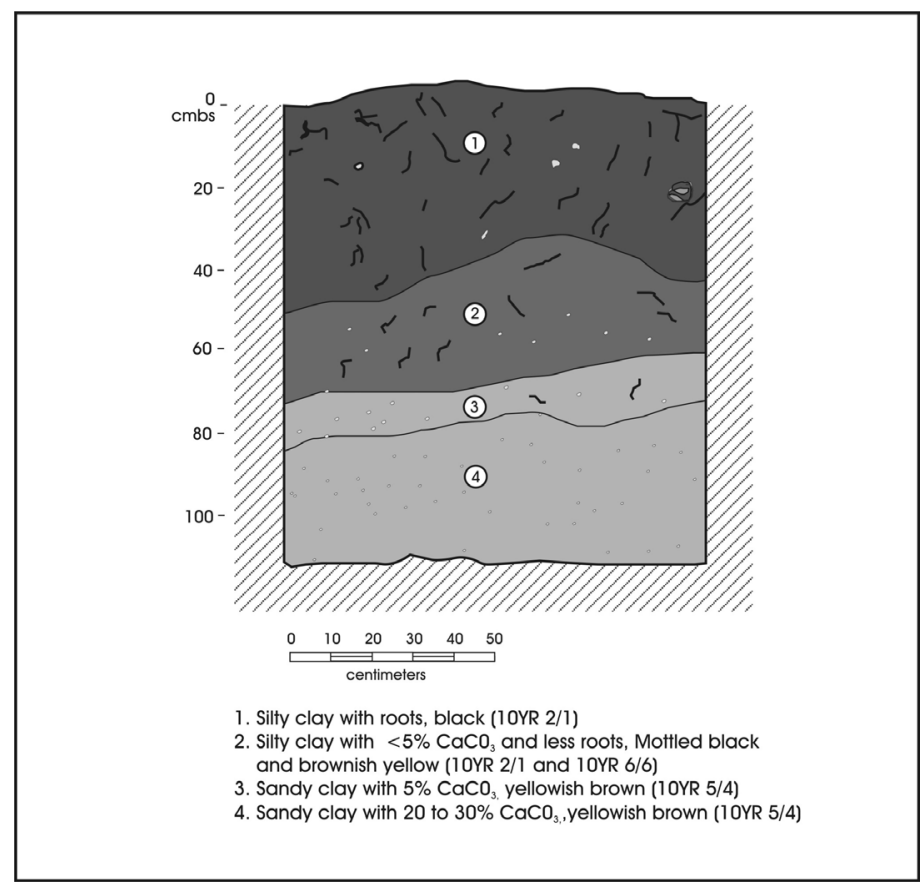

color but with $20-30 \%$ CaCO3. The only distinction between Zone 3 and 4 was the amount of $\mathrm{CaCO} 3$.

Table 4-2 presents the cultural material recovered from Test Unit 1 by level. The majority of cultural material consisted of burned rock (51\%). No features were noted in the test unit but rather the burned rock was scattered throughout the levels with most of it in Level 1 ( $n=40 ; 415.2$ grams). Heat spalls, fire-cracked chert and burned limestone composed the burned rock. Forty-one percent of the cultural material was debitage with the majority encountered in Level 6 (36\%). Four lithic tools were recovered in Levels 1, 3, 6 and 8 (refer to Chapter 5). Three Leon Plain sherds were encountered during Test Unit 1 excavations, in Levels 1 and 2. Metal and glass were found in the first level of the unit, indicating mixed deposits. The only faunal material recovered was from level 1 and consisted of chicken bone. The data in Table 4-2 shows two peaks in artifacts, one in Levels 1-2 and a second in Level 6.

Figure 4-5. Profile of the east wall of Test Unit 1. 
Table 4-2. Cultural Material Recovered from Test Unit 1

\begin{tabular}{|c|c|c|c|c|c|c|c|c|}
\hline Level & Bone & Burned Rock & Charcoal & Debitage & $\begin{array}{c}\text { Lithic Tools } \\
\text { and Cores }\end{array}$ & Ceramics & Modern & Total \\
\hline 1 & 1 & 40 & 0 & 20 & 1 & 2 & 4 & 68 \\
\hline 2 & 0 & 12 & 1 & 11 & 0 & 1 & 0 & 25 \\
\hline 3 & 0 & 3 & 1 & 1 & 1 & 0 & 0 & 6 \\
\hline 4 & 0 & 3 & 0 & 5 & 0 & 0 & 0 & 8 \\
\hline 5 & 0 & 9 & 0 & 2 & 0 & 0 & 0 & 11 \\
\hline 6 & 0 & 30 & 0 & 41 & 1 & 0 & 0 & 72 \\
\hline 7 & 0 & 26 & 0 & 17 & 0 & 0 & 0 & 43 \\
\hline 8 & 0 & 12 & 0 & 9 & 1 & 0 & 0 & 22 \\
\hline 9 & 0 & 5 & 0 & 5 & 0 & 0 & 0 & 10 \\
\hline 10 & 0 & 1 & 0 & 2 & 0 & 0 & 0 & 3 \\
\hline 11 & 0 & 0 & 9 & 0 & 0 & 0 & 0 & 9 \\
\hline Total & 1 & 141 & 11 & 113 & 4 & 3 & 4 & 277 \\
\hline
\end{tabular}

\section{Test Unit 2}

Test Unit 2 was located two meters northeast of Shovel Test 22 (Figure 4-6). The datum for this unit was located $30 \mathrm{~cm}$ south of the unit at ground surface. This unit was excavated 11 levels to $110 \mathrm{cmbd}$. This unit exhibited the same four soil zones as seen in Test Unit 1. A profile of the south wall of the unit mimicked the soils seen in the profile of Test Unit 1 (see Figure 4-5). As the case with Test Unit 1, Zone 2 contained fewer roots than Zone 1 and $<5 \%$ calcium carbonates (CaCO3). Zone 3 soil was a yellowish brown (10YR 5/4) sandy clay with $>5 \% \mathrm{CaCO} 3$, while Zone 4 consisted of the same soil color but with $20-30 \% \%$ $\mathrm{CaCO} 3$.

Material recovered from Test Unit 2 is summarized in Table 4-3. Modern material such as glass and metal were encountered in Level 1 but not collected. As seen in Test Unit 1, burned rock was the majority $(70 \%)$ of the material encountered in Test Unit 2. It did not appear that the burned rock was associated with any features but as in Test Unit 1 was scattered with a majority in Level 7 (40\%). Debitage made up $29 \%$ of the cultural material encountered. Expedient and formal lithic tools along with one core were also encountered during Test Unit 2 excavations (refer to Chapter 5). The distribution of material is similar to Test Unit 1 with a decrease after Level 2 and a peak of burned rock and debitage in Level 7.

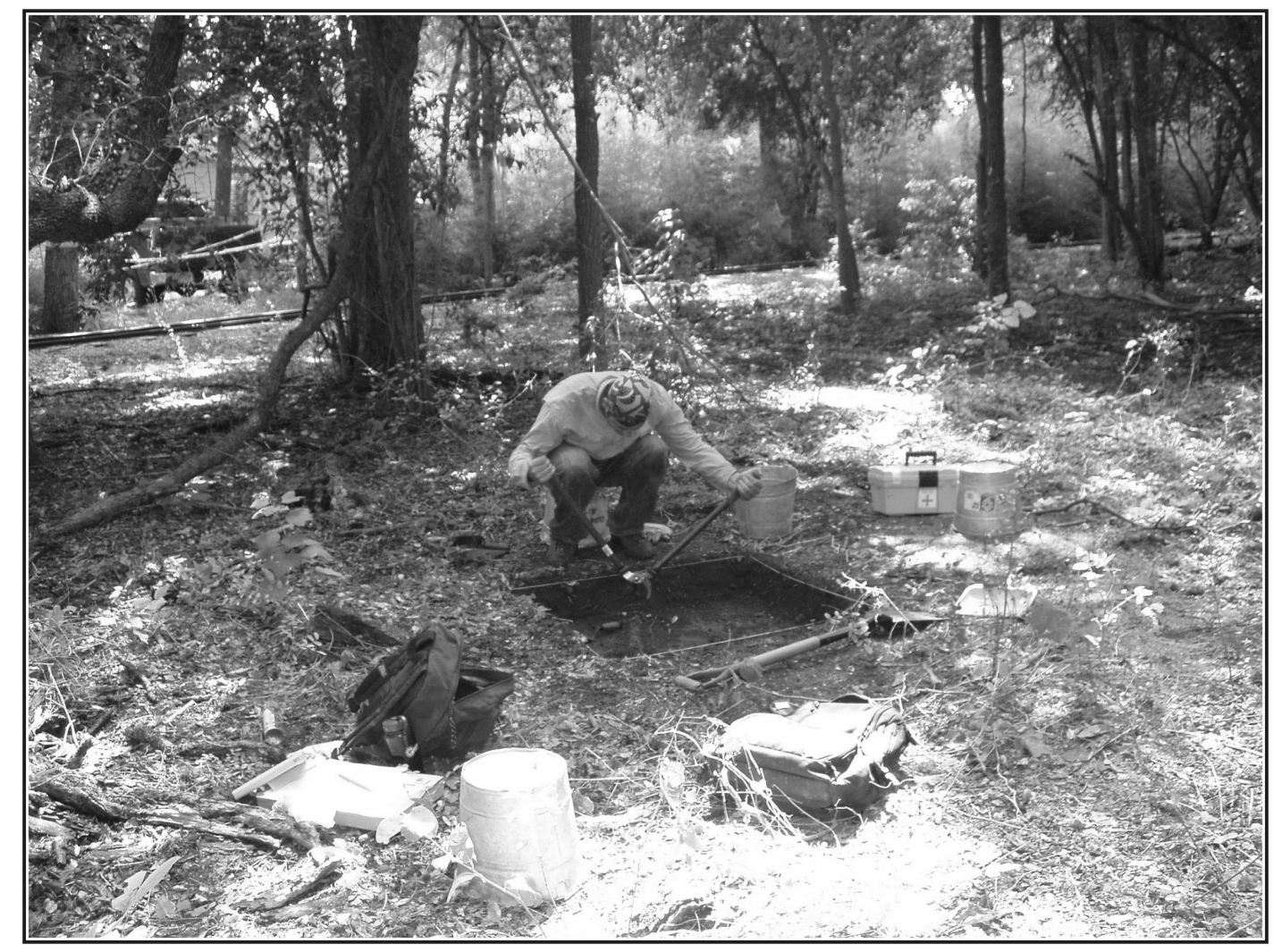

Figure 4-6. Test Unit 2 excavations. 
Table 4-3. Cultural Material Recovered from Test Unit 2

\begin{tabular}{|c|c|c|c|c|}
\hline Level & Burned Rock & Debitage & $\begin{array}{c}\text { Lithic Tools } \\
\text { and Cores }\end{array}$ & Total \\
\hline 1 & 22 & 10 & 3 & 35 \\
\hline 2 & 15 & 13 & 2 & 30 \\
\hline 3 & 0 & 1 & 0 & 1 \\
\hline 4 & 9 & 3 & 2 & 14 \\
\hline 5 & 41 & 3 & 0 & 44 \\
\hline 6 & 13 & 8 & 0 & 21 \\
\hline 7 & 95 & 44 & 1 & 140 \\
\hline 8 & 25 & 13 & 0 & 38 \\
\hline 9 & 8 & 0 & 0 & 8 \\
\hline 10 & 7 & 2 & 0 & 9 \\
\hline 11 & 1 & 0 & 0 & 1 \\
\hline Total & 236 & 97 & 8 & 341 \\
\hline
\end{tabular}

\section{Test Unit 3}

Test Unit 3 was excavated two meters north of Shovel Test 9 (Figure 4-7). The datum was set 30 centimeters $\left(250^{\circ}\right)$ southeast from unit at ground level. This unit was excavated 11 levels to $110 \mathrm{cmbd}$. The soil in this unit differed from those observed in Test Units 1 and 2. Figure 4-8 shows the profile for the west wall of the test unit with only two soil distinctions. Zone 1 consisted of a black (10YR 2/1) silty clay

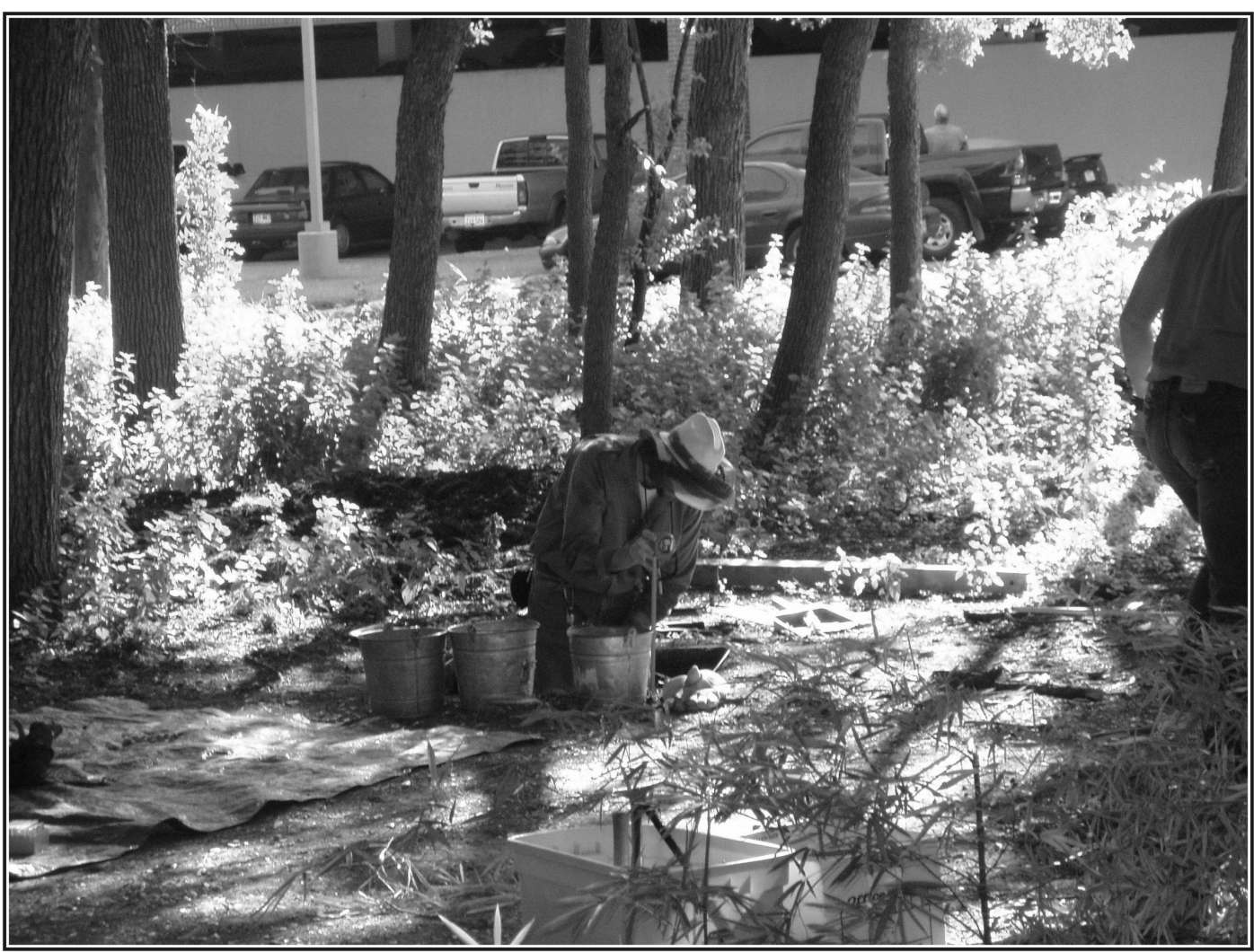

Figure 4-7. Test Unit 3 excavations.
Table 4-4. Cultural Material Recovered from Test Unit 3

\begin{tabular}{|c|c|c|c|c|c|}
\hline Level & $\begin{array}{c}\text { Burned } \\
\text { Rock }\end{array}$ & Debitage & $\begin{array}{c}\text { Lithic Tools } \\
\text { and Cores }\end{array}$ & Modern & Total \\
\hline 1 & 13 & 7 & 1 & 10 & 31 \\
\hline 2 & 13 & 8 & 0 & 0 & 21 \\
\hline 3 & 21 & 16 & 0 & 0 & 37 \\
\hline 4 & 20 & 3 & 1 & 0 & 25 \\
\hline 5 & 71 & 26 & 1 & 0 & 98 \\
\hline 6 & 26 & 23 & 0 & 0 & 49 \\
\hline 7 & 36 & 22 & 0 & 0 & 58 \\
\hline 8 & 26 & 30 & 1 & 0 & 57 \\
\hline 9 & 26 & 14 & 1 & 0 & 41 \\
\hline 10 & 8 & 8 & 1 & 0 & 17 \\
\hline 11 & 7 & 7 & 0 & 0 & 14 \\
\hline Total & 267 & 164 & 6 & 10 & 447 \\
\hline
\end{tabular}

with abundant roots. Zone 2 was a dark brown (10YR 3/3) silty clay with the presence of $\mathrm{CaCO} 3$. The lower portion of Zone 2 contained $5-10 \% \mathrm{CaCO}$. The sandy clay mottling seen in Test Units 1 and 2 was not present in Test Unit 3, nor was the heavy $\mathrm{CaCO} 3$ layer (noted as Zone 4 in TU's 1 and 2).

The material recovered from Test Unit 3 consisted for burned rock, debitage, lithic tools and cores (Table 4-4). Modern bottle glass and unidentified metal was encountered in the first level. Burned rock made up $60 \%$ of the collected material followed by debitage (37\%). Lithic tools $(\mathrm{n}=5)$ and a single core were recovered between Levels 1-10. The distribution of burned rock and debitage was different from the pattern observed in Test Units 1 and 2. Numerous peaks in cultural materials were present including Levels 1, 3,5 and 7. This could be attributed to the differences in soils zones in Test Unit 3. While Test Units 1 and 2 display similar soil strata, Test Unit 


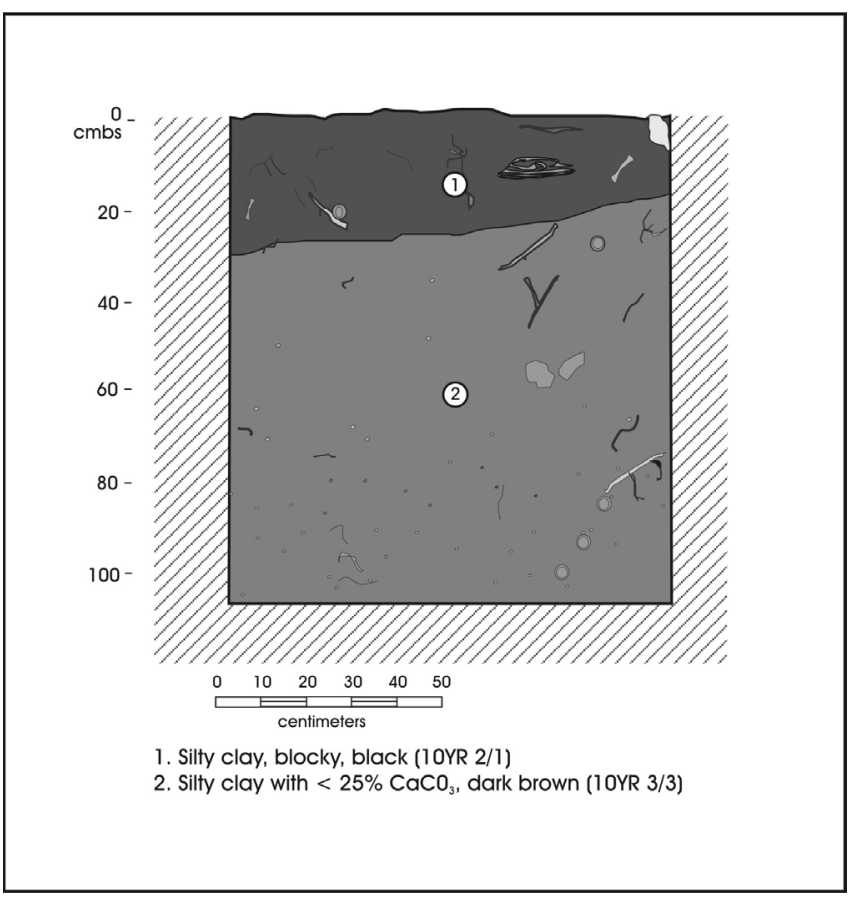

Figure 4-8. Profile of the west wall of Test Unit 3.

3 is lacking the $\mathrm{CaCO} 3$ layer and consist mostly of a dark clay matrix. This depositional sequence and the absence of an upper and a lower peak may signal that the entire deposit represents the upper component noted in the other two units.

\section{Test Unit 4}

Test Unit 4 was located between the zoo railroad track and the existing parking lot, within the bamboo thicket (Figure 4-1). The datum was set $20 \mathrm{~cm}$ west of the unit at $10 \mathrm{~cm}$ above ground surface. The test unit was excavated nine levels to $100 \mathrm{cmbd}$, just into the upper portion of the $\mathrm{CaCO} 3$ zone. Figure 4-9 illustrates the east wall profile of Test Unit 4. The soils in this unit were similar to those observed in Test Units 1 and 2. Zone 1 consisted of a black (10YR 2/1) silty clay with abundant roots. Zone 2 was a black silty clay (10YR 2/1) mottled with brownish yellow (10YR 6/6) sandy clay and $<$ $5 \% \mathrm{CaCO} 3$. A yellowish brown clay loam with $10-20 \% \mathrm{CaCO} 3$ was deemed as Zone 3.

Table 4-5 shows the artifacts retrieved from the test unit by level. Cultural material recovered included burned rock, debitage, three bifaces and one edge-modified flake. Seventy percent of the material was burned rock, followed by debitage (29\%). The three bifaces from this unit were all from the first four levels. The vertical distribution of burned rock and debitage for

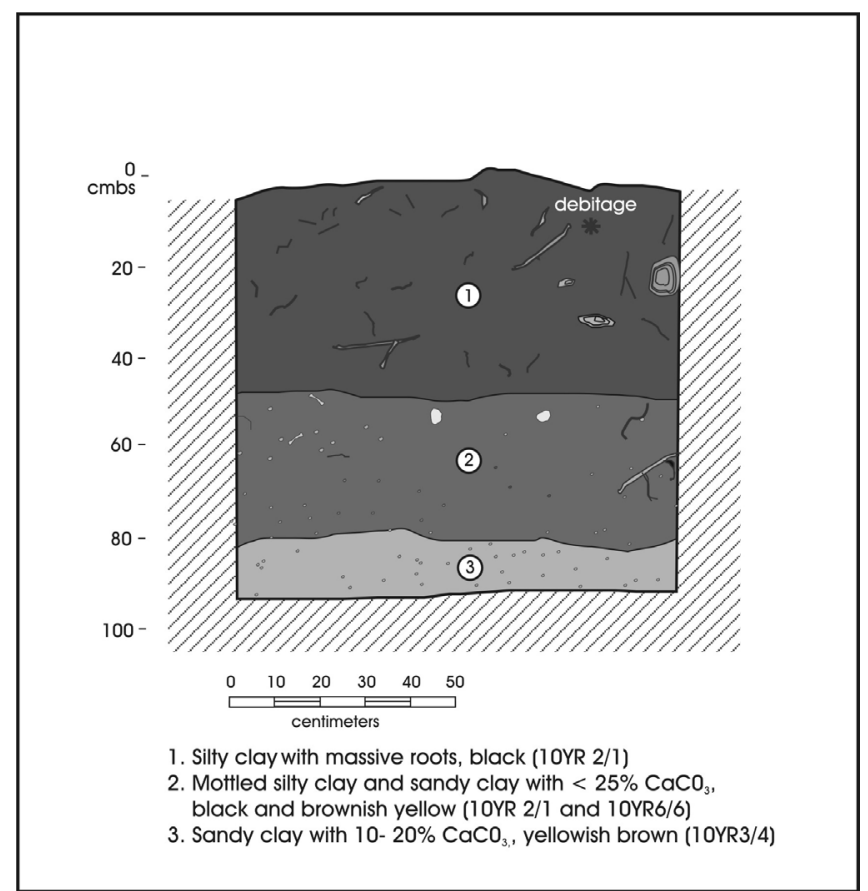

Figure 4-9. Profile of the east wall of Test Unit 4.

Test Unit 4 repeats the pattern seen in Test Units 1 and 2. A large portion of burned rock and debitage came from Level 6. Only one piece of unidentified bone was recovered in Level 6 and modern artifacts were infrequent.

\section{Summary}

CAR excavated four test units within the footprint of the parking garage facility. The distribution of cultural materials in the four units, in general shows two peaks, an upper peak in Levels 1 and 2 (TU's 1, 2, 3, and 4) and a lower peak in Levels 5 through 7 (Level 5 in TU's 2 and 3; Level 6 in TU's 1 and 4; and Levels 7 in TU's 2 and 3). As shown in Figure 4-11

Table 4-5. Cultural Material Recovered from Test Unit 4

\begin{tabular}{|c|c|c|c|c|c|c|}
\hline Level & Bone & $\begin{array}{c}\text { Burned } \\
\text { Rock }\end{array}$ & Debitage & $\begin{array}{c}\text { Lithic Tools } \\
\text { and Cores }\end{array}$ & Modern & Total \\
\hline 1 & 0 & 51 & 13 & 1 & 0 & 65 \\
\hline 2 & 0 & 71 & 13 & 1 & 0 & 85 \\
\hline 3 & 0 & 66 & 14 & 1 & 1 & 82 \\
\hline 4 & 0 & 35 & 5 & 1 & 0 & 41 \\
\hline 5 & 0 & 18 & 10 & 0 & 0 & 28 \\
\hline 6 & 1 & 65 & 51 & 0 & 0 & 117 \\
\hline 7 & 0 & 35 & 29 & 0 & 0 & 64 \\
\hline 8 & 0 & 33 & 20 & 0 & 0 & 53 \\
\hline 9 & & 17 & 6 & 0 & 0 & 23 \\
\hline Total & 1 & 391 & 161 & 4 & 1 & 558 \\
\hline
\end{tabular}


the highest densities of debitage and burned rock per cubic meter occur between Levels 5 and 7. Previous excavations at 41BX323 (Houk et al. 1999: 99) just north of the current project area (Area E) recorded a similar vertical distribution trends of burned rock and debitage.

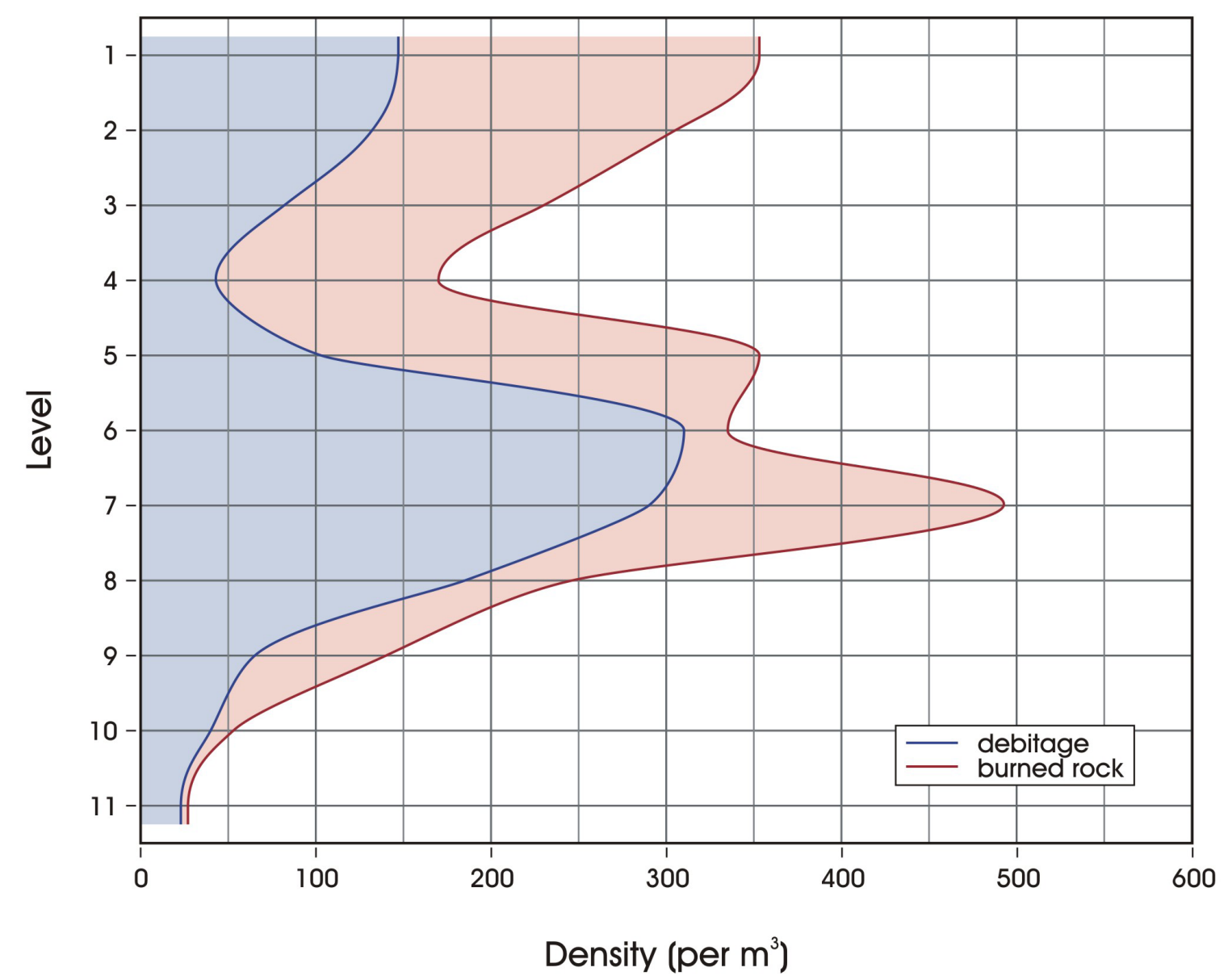

Figure 4-11. Line graph showing density of debitage and burned rock by level in the four excavated units combined. 



\section{Chapter 5: Artifact Analysis}

Test Units 1, 2 and 4 exhibit similar soil strata. Houk et al (1999:96) report similar soils in Area E of their excavations. It appears the four soil units discussed and defined by Nordt (1999) correspond to those encountered during CAR investigations. Zone 1 of the test units is probably what Nordt (1999) refers to as geomorphic Unit 3 or Unit 4, while Zone 2 is comparable to geomorphic Unit 2. Zones 3 and 4 seem to be similar to the lower portions of geomorphic Unit 2 or the upper parts of Unit 1. According to Houk et al. (1999), diagnostic artifacts from Unit 4 and the upper portions of the geomorphic Unit 3 date to the Late Prehistoric, while the lower part dates Late Archaic to Middle Archaic. Nordt suggests that Soil Unit 2 is of early to middle Holocene age with a radiocarbon date of $5500 \pm 110$ B.P and Early Archaic diagnostics. Evidence suggests that geomorphic Unit 1 is late Pleistocene in age. According to Houk et al. (1999:99) although peaks of burned rock and debitage are occurring at two different levels, the material appears where geomorphic Units 2 and 3 make contact, which is likely a stable surface.

Excavations recovered burned rock (consisting of fire cracked rock and heat spalls), ceramics, lithic debitage and tools. This chapter presents the results of a detailed lithic debitage and tool analysis. Although only three ceramic sherds were recovered from excavations, a short description is presented here as well.

\section{Debitage}

A total of 532 pieces of debitage were analyzed. Specimens included flakes and angular debris. The methodology used to characterize and interpret debitage assemblages has been extensively researched (see Andrefsky 1998; Sullivan and Rozen 1985; Mauldin and Amick 1989). Debitage attributes recorded in this analysis include, estimates of cortex percentage, maximum size $(\mathrm{mm})$, the presence or absence of patina, completeness and the number of platforms facets. The purpose of the analysis was to investigate the patterning of debitage observed in the test units (see Chapter 4; Figure 4-12). If the two peaks of debitage are indicative of different components examining the attributes by component could shed light on differences in reduction processes. For this analysis Level 1-4 are referred to as the Upper Component, while Levels 5-11 are referred to as the Lower Component. The results of the analysis are presented below are organized by analysis attribute.

\section{Cortex}

The amount of cortex on a piece of debitage is an indicator of reduction processes (Andrefsky 1998). Flakes are typically assigned as primary, secondary or tertiary, based on the amount of cortex. It is assumed that the amount of cortex should be less on late reduction specimens and greater on early reduction pieces.

In this analysis, cortex percentage was documented for each specimen. A specimen was recorded as having $0 \%$ (1), $1-25 \%$ (2), $26-50 \%$ (3), $51-75 \%$ (4) or $76-100 \%$ (5). Table 5-1 presents the cortex data by test unit. In this assemblage, $60 \%$ of the specimens were classified as having $0 \%$ cortex. Specimens that exhibited $1-25 \%$ cortex made up $30 \%$ of the assemblage, while the remainder of the collection $(9 \%)$ had $26-75 \%$ cortex present. There was absence of specimens with $76-100 \%$ cortex in all of the test units (Table 5-1). Using adjusted residuals, we also examined the debitage assemblage according to the upper and lower component defined by the vertical patterning of debitage and burned rock densities discussed in Chapter 4 (see Figure 4-12). Adjusted residuals provide information on the contribution of each individual cell to the overall contingency table. Adjusted residual values exceeding an absolute value of 1.96 suggest that the cell differences are statistically significant at a .05 level of probability. As Table 5-2 shows, specimens with $0 \%$ cortex are over represented in the lower component. Moreover, specimens exhibiting 1-25\% cortex are under represented in the lower component. This pattern suggests that the bulk of the debitage in the lower component may derive from tool rejuvenation and the later stages of raw material reduction.

Table 5-1. The Percentage of Cortex by Test Unit

\begin{tabular}{|c|c|c|c|c|c|c|}
\hline $\begin{array}{c}\text { Test } \\
\text { Unit }\end{array}$ & $\mathbf{0 \%}$ & $\mathbf{1 - 2 5 \%}$ & $\mathbf{2 6 - 5 0 \%}$ & $\mathbf{5 1 - 7 5 \%}$ & $\begin{array}{c}\mathbf{7 6 -} \\
\mathbf{1 0 0 \%}\end{array}$ & Total \\
\hline 1 & 80 & 22 & 11 & 0 & 0 & 113 \\
\hline 2 & 62 & 21 & 9 & 2 & 0 & 94 \\
\hline 3 & 128 & 25 & 8 & 3 & 0 & 164 \\
\hline 4 & 121 & 32 & 8 & 0 & 0 & 161 \\
\hline Total & 391 & 100 & 36 & 5 & 0 & 532 \\
\hline
\end{tabular}


Table 5-2. Percentage of Corticate Debitage for

Upper and Lower Component of 41BX323

\begin{tabular}{|c|c|c|c|c|}
\hline Cortex \% & & $\begin{array}{c}\text { Upper } \\
\text { Component }\end{array}$ & $\begin{array}{c}\text { Lower } \\
\text { Component }\end{array}$ & Total \\
\hline \multirow{2}{*}{0} & Count & 86 & 305 & 391 \\
\cline { 2 - 5 } & $\begin{array}{c}\text { Adjusted } \\
\text { Residual }\end{array}$ & $\mathbf{- 4 . 2}$ & $\mathbf{4 . 2}$ & \\
\hline \multirow{2}{*}{$1-25$} & Count & 44 & 56 & 100 \\
\cline { 2 - 5 } & $\begin{array}{c}\text { Adjusted } \\
\text { Residual }\end{array}$ & $\mathbf{4 . 3}$ & $\mathbf{- 4 . 3}$ & \\
\hline \multirow{2}{*}{$26-50$} & Count & 10 & 26 & 36 \\
\cline { 2 - 5 } & $\begin{array}{c}\text { Adjusted } \\
\text { Residual }\end{array}$ & 0.1 & -0.1 & \\
\hline \multirow{2}{*}{$51-75$} & Count & 3 & 2 & 5 \\
\cline { 2 - 5 } & $\begin{array}{c}\text { Adjusted } \\
\text { Residual }\end{array}$ & 1.7 & -1.7 & \\
\hline Total & & 143 & 389 & 532 \\
\hline $\mathrm{p}=.00$ & \multicolumn{3}{|c}{} \\
\hline
\end{tabular}

\section{Maximum Dimension}

The maximum dimension of each specimen was also examined. The dimension of a specimen should be indicative of reduction processes as noted earlier, the smaller the piece of debitage the closer to completion the end product is assumed to be. The average size of specimens for all of the assemblage is 21.05 millimeters $(\mathrm{mm})$. Examining the assemblage according to the two defined components there is not a significant difference in debitage size. When comparing cortex percentage with size those specimens with no cortex are smaller in size than those with $26-75 \%$ cortex (Figure $5-1)$. This pattern remains consistent between the upper and lower component. Therefore, in this instance the length of the specimen appears to correlate with the amount of cortex and supports the idea that larger specimens are derived from the early stages of reduction. This pattern is also consistent with the observation that the debitage in the lower component may consist primarily of late reduction stage flake and debris from tool rejuvenation.

\section{Patina}

An additional attribute that was recorded for each specimen was the presence or absence of patina. The amount of patina on a specimen has been used to infer age. It is typically thought that the presence of patina is correlated with older materials. At several sites it has been recorded that the occurrence of patinated material increases with depth (Frederick et al. 1994; Bement 1989). Overall, thirty-two percent of the assemblage is patinated. As seen in Table 5-3 the chi-squared (40.97, $\mathrm{p}<.000, \mathrm{df}=1)$ proved to be significant indicating that patinated materials tend to be more frequent in the lower component.
Table 5-3. Presence/Absence of Patina by Component

\begin{tabular}{|c|c|c|c|c|}
\hline & & $\begin{array}{c}\text { Upper } \\
\text { Component }\end{array}$ & $\begin{array}{c}\text { Lower } \\
\text { Com- } \\
\text { ponenet }\end{array}$ & Total \\
\hline Absent & $\begin{array}{c}\text { Observed } \\
\text { Count }\end{array}$ & 128 & 236 & $\mathbf{3 6 4}$ \\
\hline Present & $\begin{array}{c}\text { Observed } \\
\text { Count }\end{array}$ & 15 & 153 & $\mathbf{1 6 8}$ \\
\hline Total & & 143 & 389 & $\mathbf{5 3 2}$ \\
\hline
\end{tabular}

Chi Square $=40.257, \mathrm{p}<.000, \mathrm{df}=1$

\section{Breakage Patterns}

The condition of each specimen was noted as being complete, platform bearing, medial/distal, or angular debris in order to examine the variation of breakage patterns. Research has concluded that breakage patterns can be attributed to reduction activities (Sullivan and Rozen 1985) and raw material type (Amick and Mauldin 1997). A majority $(50.6 \%)$ of the debitage is composed of complete flakes. Thirty-five percent of the assemblage consisted of medial/ distal flakes. Platform bearing flakes only made up $12.4 \%$ of the assemblage, followed by angular debris $(2.1 \%)$. The upper and lower component of the site exhibit slightly different breakage patterns. Table 5-4 indicates that the lower component has a higher frequency of complete flakes than the upper component but in general complete flakes are under-represented relative to fragmentary flakes in the lower component. In contrast, medial/distal flakes are overrepresented in the lower component comparted to the upper component. The chi-square indicates that the difference in breakage patterns between the two components is significant (with 98\% confidence).

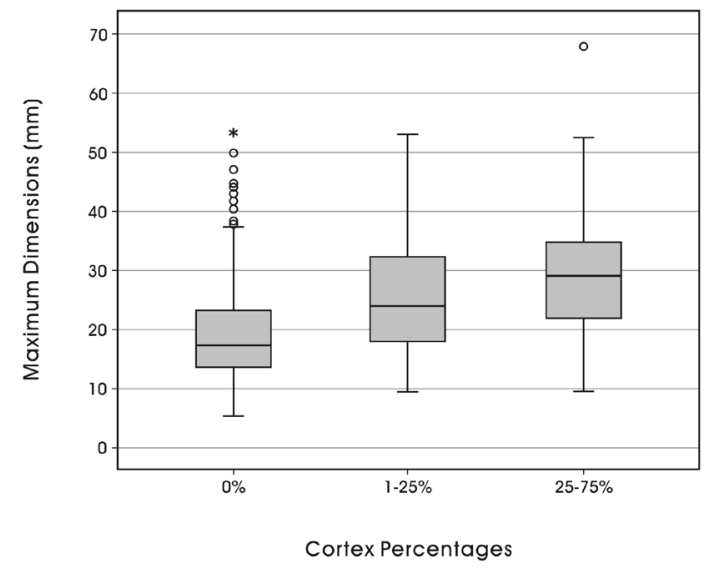

Figure 5-1. Box plot exhibiting maximum dimension of debitage by cortex percentages. 
Table 5-4. Breakage Patterns by Component

\begin{tabular}{|c|c|c|c|c|}
\hline & & $\begin{array}{c}\text { Upper } \\
\text { Component }\end{array}$ & $\begin{array}{c}\text { Lower } \\
\text { Component }\end{array}$ & Total \\
\hline \multirow[b]{2}{*}{ complete } & Count & 84 & 185 & 269 \\
\hline & $\begin{array}{l}\text { Adjusted } \\
\text { Residual }\end{array}$ & 2.3 & -2.3 & \\
\hline \multirow{2}{*}{$\begin{array}{c}\text { platform } \\
\text { bearing }\end{array}$} & Count & 18 & 48 & 66 \\
\hline & $\begin{array}{l}\text { Adjusted } \\
\text { Residual }\end{array}$ & 0.1 & -0.1 & \\
\hline \multirow{2}{*}{$\begin{array}{c}\text { medial/ } \\
\text { distal }\end{array}$} & Count & 36 & 150 & 186 \\
\hline & $\begin{array}{l}\text { Adjusted } \\
\text { Residual }\end{array}$ & -2.9 & 2.9 & \\
\hline \multirow{2}{*}{$\begin{array}{l}\text { angular } \\
\text { debris }\end{array}$} & Count & 5 & 6 & 11 \\
\hline & $\begin{array}{l}\text { Adjusted } \\
\text { Residual }\end{array}$ & 1.4 & -1.4 & \\
\hline Total & & 143 & 389 & 532 \\
\hline
\end{tabular}

Chi Square $=9.88, \mathrm{p}<.02, \mathrm{df}=3$

\section{Platform Facets}

It has been suggested that the number of facets on the platform is telling of reduction and whether core reduction or tool reduction was occurring (Andrefsky 1998, Tomka 1989 and 2001). Single facet platforms are indicative of core reduction while, tool reduction should result in multiple-faceted flakes. This attribute could only be recorded on complete or platform bearing pieces. The majority (63\%) of the specimens included in this analysis possessed single platform facets, while $27 \%$ exhibited three or more platform facets. Only $10 \%$ of the examined specimens exhibited two platform facets

\section{Lithic Tools}

As the case with debitage analysis, bifacial lithic tools are typically discussed in terms of reduction stage (i.e., early, middle or late reduction or finished). Twenty-three lithic tools were encountered during excavations at 41BX323 they included bifaces $(\mathrm{n}=11)$, cores $(\mathrm{n}=2)$, retouched/use-modified flakes $(\mathrm{n}=9)$ and one uniface (Table 5-5). The most frequent

Table 5-5. Lithic Tools and Cores Recovered from Test Unit Excavations

\begin{tabular}{|c|c|c|c|c|c|c|c|c|c|}
\hline TU & Level & Tool & Count & Length (mm) & Width (mm) & Thickness (mm) & W/T Ratio & Tool Completeness & Break Cause \\
\hline 1 & 1 & edge-modified & 1 & 24.03 & 17.1 & 4.43 & 3.9 & complete & na \\
\hline 1 & 3 & biface & 1 & na & 29.7 & 4.9 & 6.1 & distal & manufacture \\
\hline 1 & 6 & biface & 1 & na & 12.7 & 4.8 & 2.6 & proximal & manufacture \\
\hline 1 & 8 & biface & 1 & na & 22.3 & 10.4 & 2.1 & distal & manufacture \\
\hline 2 & 1 & biface & 1 & na & 37.1 & 17.4 & 2.1 & distal & manufacture \\
\hline 2 & 1 & core & 1 & 38.25 & 22.03 & 6.34 & 3.5 & na & na \\
\hline 2 & 1 & uniface & 1 & na & 34.9 & 29 & 1.2 & distal & manufacture \\
\hline 2 & 2 & biface & 1 & na & 33.12 & 14.48 & 2.3 & medial & manufacture \\
\hline 2 & 2 & edge-modified & 1 & 20.34 & 33.08 & 13.93 & 2.4 & complete & na \\
\hline 2 & 4 & biface & 1 & na & 21.8 & 8.4 & 2.6 & distal & manufacture \\
\hline 2 & 4 & retouched flake & 1 & 59.48 & 44.69 & 19.27 & 2.3 & complete & na \\
\hline 2 & 7 & edge-modified & 1 & 43.44 & 36 & 11.31 & 3.2 & complete & na \\
\hline 3 & 1 & edge-modified & 1 & 29 & 10.83 & 5.24 & 2.1 & complete & na \\
\hline 3 & 4 & core & 1 & 79.3 & 55.8 & 42.6 & 1.3 & na & na \\
\hline 3 & 4 & edge-modified & 1 & na & 12.34 & 2.74 & 4.5 & distal & na \\
\hline 3 & 5 & retouched flake & 1 & na & 34.59 & 13.1 & 2.6 & distal & na \\
\hline 3 & 8 & biface & 1 & na & 14.5 & 8 & 1.8 & distal & manufacture \\
\hline 3 & 9 & edge-modified & 1 & na & 16.9 & 5.95 & 2.8 & distal & na \\
\hline 3 & 10 & biface & 1 & na & 25.8 & 8.2 & 3.1 & distal & manufacture \\
\hline 4 & 1 & biface & 1 & na & 22.34 & 9.42 & 2.4 & medial & manufacture \\
\hline 4 & 2 & edge-modified & 1 & 18.24 & 15.63 & 3.61 & 4.3 & complete & na \\
\hline 4 & 3 & biface & 1 & na & 24.9 & 10.7 & 2.3 & proximal & post-depostional \\
\hline 4 & 4 & biface & 1 & na & 18.26 & 4.57 & 4 & medial & manufacture \\
\hline \multicolumn{3}{|c|}{ Total } & 23 & & & & & & \\
\hline
\end{tabular}


tool types to be recovered from excavations were bifaces $(n=11)$. Few cores $(n=2)$ and informal tools such as edgemodified flakes $(n=7)$, unifaces $(n=1)$ and retouched flakes $(n=2)$ were encountered.

No complete bifaces were recovered (Figure 5-2a-d). Furthermore, a majority of the biface fragments appeared to be broken during manufacture, except for one biface fragment recovered from Test Unit 4 Level 3, with appeared to exhibit post-depositional breakage. All of the tools and cores were produced from chert material with the exception of a quartzite biface fragment found in Test Unit 3, Level 8. The width/thickness ratio was calculated for the bifaces. A small ratio indicates late reduction while larger ratios denote early reduction. Although the width/thickness ratio for the bifaces ranged from 2.1 to 3.9, one biface possessed a width/ thickness ratio of 6.1 (see Figure 5-2a).

The distal end of a uniface tool was recovered from Test Unit 1, Level 1. Two muliti-directional cores were found during excavations, from Test Units 2 (Level 1) and 3 (Level 4). The specimens were reduced to exhausted conditions. Seven edge-modified flakes and two retouched flakes were recovered from excavations. One of these expedient tools was produced from a blade (see Figure 5-2e) that was detached from a core. It was from Test Unit 3 Level 1. Blades are common in Toyah Phase sites and Colonial period sites (Hester 1977).

\section{Native American Ceramics}

Three Leon Plain ceramic sherds were encountered during investigations at 41BX323. Leon Plain wares were manufactured during the later part of the Late Prehistoric period known as the Toyah Phase. Johnson (1994) suggests in the Classic Toyah, which began around 1300 AD. The producers of Leon Plain wares were mobile hunter-gatherer groups. The main characteristic of the ware is bone tempering. Vessel forms are simple and consist of jars, ollas and bowls. The forms suggest the wares probably functioned as cooking, serving and water containers (Johnson 1994). The average thickness of the three sherds is $3.65 \mathrm{~mm}$. All three sherds possessed polished exterior and interior surfaces and are perhaps the remnants of a bowl vessel. The cores of all three sherds are blackened.

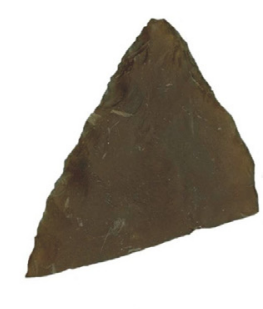

a

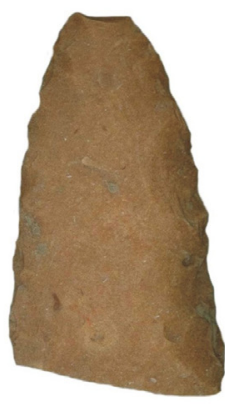

d

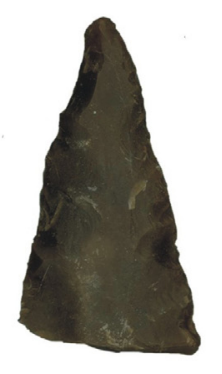

b

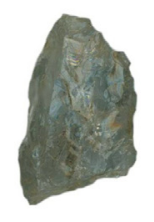

c
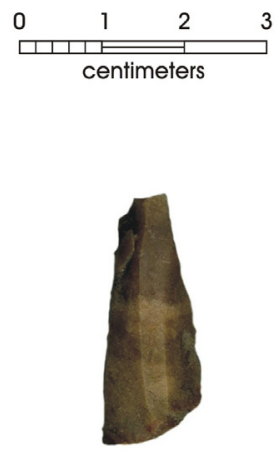

e

Figure 5-2. Lithic tools from 41BX323: a-d) bifaces e) edge-modified blade 


\section{Chapter 6: Conclusions and Recommendations}

CAR conducted archaeological testing in September 2007 on untested portions of SAL site 41BX323 prior to the construction of a parking garage facility. The primary goal of CAR's archaeological investigation was to determine if the proposed impacts would adversely affect deposits that contribute to the site's SAL eligibility. The second goal of archaeological investigations was to better define the southern boundary of the site. Archaeological investigations conducted by CAR resulted in the excavation of twentyseven shovel tests, two backhoe trenches and four 1-x-1 meter units. Unfortunately, the existing parking lot and Parks and Recreation buildings hindered the archaeological investigation of the southern portions of the APE.

Test unit excavations revealed burned rock, lithic debitage and tools. The only diagnostic materials recovered were three Leon Plain sherds that were recovered from the upper levels of test unit excavation. Soil units described in previous investigations (Houk et al. 1999) appear to be present in the area investigated by CAR. According to the geomorphological studies conducted by Nordt (1999), the earliest soil unit formed during the Pleistocene. CAR test units might have encountered Soil Units 3 (Late Prehistoric to Middle Archaic) and 2 (Early Archaic). The presence of a Late Prehistoric occupation was evident with the recovery of Leon Plain ceramics but they were found with modern debris, suggesting disturbance to this portion of the site.

Although the high density of lithic debitage and burned rock occurring between Levels 5 and 7 (in conjunction with the previous geomorphological findings) suggests the presence of an Early Archaic component, no diagnostics were recovered. Houk et al. (1999:99) observed a similar pattern in their Test Units E-1 through E-3. The results of the debitage analysis revealed some differences between the upper and lower component assemblages, particularly in terms of the representation of corticated debitage, patination and the relative proportions of complete flakes. In general, the lower component tends to be represented by a high frequency of late reduction stage and/or tool rejuvenation debitage. The lower component also tends to have a higher representation of patinated debitage.

In conclusion, the finding of cultural material outside of the previous site limits suggests that the site boundary needs to be extended further south than previously recorded (Figure 6-1). CAR recommends that, although the cultural material recovered during excavations likely represents Late Prehistoric to Archaic occupation of the site, no significant data, within the tested portion of the site would contribute to the understanding of Texas prehistory. Also, no intact features were identified although small pieces of fire-cracked rock were quite common on site. CAR recommends that the tested portion of the site does not contribute to the site's SAL eligibility. The cluster of negative shovel tests located in the vicinity of the Park and Recreation facility suggests that the site boundary does not extend under the disturbed area. Therefore, CAR recommends no additional archaeological investigations of the APE.

During the review of the draft final report, the THC reviewer, Mark Denton, concurred with the CAR recommendations and also requested that the City Parks and Recreation Department coordinate with the THC regarding the movement of the maintenance facility found within the boundaries of the project area. In addition, the THC requested that Lake/Flato Architects coordinate with the THC regarding the relocation of the mini-railroad from within the footprint of the planned parking facility. Since the new location will fall within the limits of site 41BX323, it is paramount that no subsurface disturbances occur during the reinstallation of the tracts. The CAR Principal Investigator informed Kim Monroe of Lake/ Flato Architects of the need for coordination regarding the facilities and railroad relocations. Additional coordination with THC will be handled by the architectural firm. 
This page has been

redacted because it

contains restricted

information. 


\section{References Cited}

Amick, D. and R.P. Mauldin

1997 Effects of Raw Material on Flake Breakage Patterns. Lithic Technology 22(1):18-32.

Andrefsky, W., Jr.

1998 Lithics: Macroscopic Approaches to Analysis. Cambridge University Press.

Banks, L.D.

1990 From Mountain Peaks to Alligator Stomachs: A Review of Lithic Resources in the Trans-Mississippi South, the Southern Plains, and Adjacent Southwest. Memoir 4. Oklahoma Anthropological Society, Oklahoma City.

Barker, R.A., P.W. Bush, and E.T. Baker, Jr.

1994 Geologic History and Hydrogeologic Setting of the Edwards-Trinity Aquifer System, West-Central Texas. WaterResources Investigations Report 94-4039. U.S. Geological Survey, Austin.

Barnes, V.E.

1983 Geologic Atlas of Texas: San Antonio Sheet. Bureau of Economic Geology, The University of Texas.

Bement, L.C.

1989 Excavations at 41BP19: The Kennedy Bluffs Site, Bastrop County, Texas. Texas Archaeological Research Laboratory, The University of Texas at Austin. Contract Reports in Archaeology Report No. 5. Highway Design Division, Texas State Department of Highways and Public Transportation, Austin.

Black, S.L.

1989 Central Texas Plateau Prairie. In From the Gulf to the Rio Grande: Human Adaptation in Central, South, and Lower Pecos Texas, by T.R. Hester, S.L. Black, D.G. Steele, B.W. Olive, A.A. Fox, K.J. Reinhard, and L.C. Bement, pp. 1736. Research Series No. 33. Arkansas Archeological Survey, Fayetville.

Black, S.L. and D.G. Creel

1997 The Central Texas Burned Rock Midden Reconsidered. In Hot Rock Cooking on the Greater Edwards Plateau: Four Burned Rock Midden Sites in West Central Texas, by Steve Black, Linda W. Ellis, Darrell G. Creel, and Glenn T. Goode, pp.269-305. Studies in Archeology 2. Texas Archeological Research Laboratory, The University of Texas at Austin.

Black, S.L., K. Jolly, C.D. Frederick, J.R. Lucas, J.W. Karbula, P.R. Takac, and D.R. Potter 1998 Investigations and Experimentation at the Higgins Site (41BX184). Archeology along the Wurzbach Parkway, Module 3. Studies in Archeology 27. Texas Archeological Research Laboratory, The University of Texas at Austin.

Black, S.L., and A.J. McGraw

1985 The Panther Springs Creek Site: Cultural Change and Continuity within the Upper Salado Creek Watershed, SouthCentral Texas. Archeological Survey Report No. 100. Center for Archaeological Research, The University of Texas at San Antonio.

Blair, W.F.

1950 The Biotic Provinces of Texas. Texas Journal of Science 2(1):93-117. 
Bomar G.W.

1983 Texas Weather. University of Texas Press, Austin.

Brune, G.

1981 Springs of Texas. Vol. 1. Branch-Smith, Inc., Fort Worth.

Campbell, T.N.

1983 Coahuiltecans and Their Neighbors. In Handbook of North American Indians, Vol. 10, edited by W.C. Sturtevant, pp. 343-358. Smithsonian Institution, Washington, D.C.

Collins, M.B.

1995 Forty Years of Archeology in Central Texas. Bulletin of the Texas Archaeological Society 66:361-400.

Collins, M.B., D.B. Hudler, and S.L. Black

2003 Pavo Real (41BX52): A Paleoindian and Archaic Camp and Workshop on the Balcones Escarpment, South-Central Texas. Studies in Archeology 41. Texas Archeological Research Laboratory, The University of Texas at Austin and Archeological Studies Program Report 50 Environmental Affairs Division, Texas Department of Transportation. Austin.

Cox, I.W.

1997 The Growth of San Antonio. In Archaeology at the Alamodome: Investigations of a San Antonio Neighborhood in Transition, Vol. I, Historical Architectural, and Oral History Research, edited by A.A. Fox, M. Renner, and R.J. Hard, pp. 8-44. Archaeological Survey Report No. 236. Center for Archaeological Research, The University of Texas at San Antonio.

Cox, I.W., E.D. Johnson, and C.B. Bousman

1999 Excavations for the Upper Labor Dam Site, Brackenridge Park, San Antonio, Bexar County, Texas. Archaeological Survey Report, No. 268. Center for Archaeological Research, The University of Texas at San Antonio.

Foley, D., and C.M. Woodruff, Jr.

1986 Geothermal Resources of Bexar County, Texas. In The Balcones Escarpment, Central Texas, edited by P.L. Abbott and C.M. Woodruff, pp. 145-152. Geological Society of America.

Fox, A.A.

1979 A Survey of Archeological, Architectural and Historical Sites on the San Antonio River from Olmos Dam to South Alamo Street and on San Pedro Creek from San Pedro Park to Guadalupe Street. Archaeological Survey Report No. 80. Center for Archaeological Research, The University of Texas at San Antonio.

Frederick, C., and C.W. Ringstaff

1994 Lithic Resources at Fort Hood: further investigations. In Archaeological Investigations on 571 Prehistoric Sites at Fort Hood, Bell, and Coryell Counties, Texas, edited by W.N. Trierweiler, pp. 125-181. Research Report No. 31, Archaeological Resource Management Series. U.S. Army, Fort Hood.

Frederick, C.D., M.D. Glascock, H. Neff and C.M. Stevenson

1994 Evaluation of Chert Patination as a Dating Technique: A Case Study from Fort Hood, Texas. Mariah Associates, Austin. Research Report No. 32. Archaeological Resource Management Series, United States Army, Fort Hood.

Gould, F.W.

1969 Texas Plants: A Checklist and Ecological Survey. Texas Agricultural Extension Service, Texas A\&M University, College Station. 
Henderson, J., and G.T. Goode 1991 Pavo Real: An Early Paleoindian Site in South-Central Texas. Current Research in the Pleistocene 8:26-28.

Hester, T.R.

1977 The Lithic Technology of Mission Indians in Texas and Northeastern Mexico. Lithic Technology 6(1):9-13.

1978 Early Human Occupations in South Central and Southwestern Texas: Preliminary Papers on the Baker Cave and St. Mary's Hall Sites. Center for Archaeological Research, The University of Texas at San Antonio.

1989 Historic Native American Populations, in From the Gulf to the Rio Grande: Human Adaptation in Central, South, and Lower Pecos Texas, by T.R. Hester, S.L. Black, D.G. Steele, B.W. Olive, A.A. Fox, K.J. Reinhard, and L.C. Bement, pp. 77-84. Research Series No. 33. Arkansas Archeological Survey, Fayetville.

1990 Plainview Artifacts at the St. Mary's Hall Site, South Central Texas. Current Research in the Pleistocene 7:14-17.

1995 The Prehistory of South Texas. Bulletin of the Texas Archeological Society 66:427-459.

Houk, B.A.

2002 Brackenridge Park Rehabilitation Project: Data Recovery at 41 BX323 and Testing at 41BX1425 San Antonio, Bexar County, Texas. SWCA Cultural Resource Report No. 01-357. SWCA, Inc., Austin

Houk, B.A. and K.A. Miller 2001 Brackenridge Park Rehabilitation Project Archaeological Survey, San Antonio, Bexar County, Texas. SWCA Cultural Resource Report No. 00-331. SWCA, Inc., Austin.

Houk, B.A., K.A. Miller, R.K. Meadows, and C.W. Ringstaff

1999 Archaeological Excavations at 41BX323, Brackenridge Park, San Antonio, Bexar County, Texas. SWCA Cultural Resource Report No. 99-67. SWCA, Inc., Austin.

Katz, S.R. and A.A. Fox

1979 Archaeological and Historical Assessment of Brackenridge Park, City of San Antonio, Texas. Archaeological Survey Report No. 33. Center for Archaeological Research, The University of Texas at San Antonio.

Katz, S.R., and P.R. Katz

1982 Report of Archeological Testing at 41BX291 in the Southern Olmos Basin, Bexar County, Texas by the 1976 Incarnate Word Archeological Field School. Unpublished report prepared for the Texas Antiquities Committee.

Johnson, L.

1994 The Life and Times of Toyah-Culture Folk: The Buckhollow Encampment, Site 41KM16, Kimble County, Texas. Office of the State Archeologist Report 38. Texas Department of Transportation and Texas Historical Commission, Austin.

Mauldin, R.P. and D.S. Amick

1989 Investigating Patterning from Experimental Bifacial Core Reduction. In Experiments in Lithic Technology, edited by D.S. Amick and R.P. Mauldin, pp. 88-100. British Archaeological International Series 528, Oxford.

Meltzer D.J. and M.R. Bever

1995 Paleoindians of Texas: An Update on the Texas Clovis Fluted Point Survey. Bulletin of the Texas Archaeological Society 66:47-81.

Meskill, F.H. and C.D. Frederick

1998 Archaeological Testing at the Witte Museum Science Facility Construction Site: An Archaeological and Geoarchaeological Study on the East Bank of the San Antonio River. Technical Series 48. Texas Archaeological Research Laboratory, The University of Texas, Austin. 
Meskill, F.H., L.C. Shaw, and S.L. Black

2000 Exavations at 41BX323, the Witte Museum Parcel: Archaic Period Occupation on the Banks of the San Antonio River, Bexar County, Texas. Technical Series 50. Texas Archaeological Research Laboratory, The University of Texas, Austin.

McKinney, W.W.

1981 Early Holocene Adaptations in Central and Southern Texas: The Problem of the Paleoindian-Archaic Transition. Bulletin of the Texas Archaeological Society 52:91-120.

Miller, K.A., S. Carpenter, L.C. Nordt, C. Howell, and C. Ringstaff

1999 Archaeological Testing of 41 BX323 and Portions of the Historic Second Waterworks Canal. Brackenridge Park, San Antonio, Bexar County, Texas. SWCA Cultural Resource Report No. 98-62. SWCA, Inc., Austin.

Nordt, L.C.

1999 Geoarchaeology of Site 41BX323. In Archaeological Excavations at 41BX323, Brackenridge Park, San Antonio, Bexar County, Texas, by B.A. Houk., K.A. Miller, R.K. Meadows, and C.W. Ringstaff, pp. 47-66. SWCA Cultural Resource Report No. 99-67. SWCA, Inc., Austin.

Orchard, C.D., and T.N. Campbell

1954 Evidence of Early Man from the Vicinity of San Antonio, Texas. Texas Journal of Science 6(4):454-465.

Perttula, T.K., M.R. Miller, R.A. Ricklis, D.J. Prikryl, and C. Lintz 1995 Prehistoric and Historic Aboriginal Ceramics in Texas. Bulletin of the Texas Archeological Society 66:175-235.

Potter, D.R., and S.L. Black

1995 Archeology Along the Wurzbach Parkway, Module 2: Initial Testing and Evaluation of Five Prehistoric Sites in the Upper Salado Watershed, Bexar County, Texas. Studies in Archeology 18. Texas Archeological Research Laboratory, The University of Texas at Austin.

Potter, D.R., and S.L. Black, and K. Jolly

1995 Archeology Along the Wurzbach Parkway, Module 1: Introduction, Conceptual Framework, and Contexts of Archeological Investigations in Bexar County, South-Central Texas. Studies in Archeology 17. Texas Archeological Research Laboratory, The University of Texas at Austin.

Prewitt, E.R.

1981 Culture Chronology in Central Texas. Bulletin of the Texas Archeological Society 52:65-89.

Ricklis, R.A.

1992 The Spread of the Late Prehistoric Bison Hunting Complex: Evidence from the South-Central Coastal Prairie of Texas. Plains Anthropologist 37(140):261-273.

Story, D.A.

1985 Adaptive Strategies of Archaic Cultures of the West Gulf Coastal Plain. In Prehistoric Food Production in North America, edited by R.I. Ford, pp. 19-56. Anthropological Papers No. 75. Museum of Anthropology, University of Michigan, Ann Arbor.

Spearing, D.

1992 Roadside Geology of Texas. Mountain Press Publishing Company, Missoula, Montana. 
Stothert, K.E.

1989 The Archeology and Early History of the Head of the San Antonio River. Southern Texas Archeological Association Special Publication No. 5 and Incarnate Word College Archeology Series No 3. San Antonio.

Sullivan, A.P., III and K. Rozen

1985 Debitage Analysis and Archaeological Intrepretation. American Antiquity 50(4):755-779.

Taylor, F.B., R.B. Hailey, and D.L. Richmond 1991 Soil Survey, Bexar County, Texas. Soil Conservation Service, U.S. Department of Agriculture, Washington D.C.

Texas Historical Commission (THC)

2007 Texas Archeological Sites Atlas. http://nueces.thc.state.tx.us. Accessed October 12, 2007.

Thompson, J. L.

2006 Interim Report of Findings During Additional Testing of the Granberg Site (41BX17). Manuscript on file at the Center for Archaeological Research, The University of Texas at San Antonio.

Tomka, S.A.

1989 Differentiating Lithic Reduction Techniques: An Experimental Approach. In Experiments in Lithic Technology, edited by D. S. Amick and R. P. Mauldin, pp. 137-161. British Archaeological Reports International Series 528, Oxford.

2001 Chapter 10: Lithic Artifacts. In Archaeological Investigations at a Spanish Colonial Site, (41KA26-B), Karnes County, Texas, edited by C.L. Tennis, pp. 65-71. Archaeological Research Report No. 302. Center for Archaeological Research, The University of Texas at San Antonio.

Turner, S.E., and T.R. Hester

1993 Stone Artifacts of Texas Indians. Second Edition. Texas Monthly and Gulf Publishing Company, Houston.

Webb, W.P. (editor)

1952 The Handbook of Texas. 2 Vols. Texas State Historical Association, Austin.

Weir, F.A.

1976 The Central Texas Archaic. Unpublished Ph.D. dissertation. Department of Anthropology, Washington State University, Pullman. 